\title{
A Study of the Mechanism of $\mathrm{Ca}^{2+}$ Current Inhibition Produced by Serotonin in Rat Dorsal Raphe Neurons
}

\author{
Nicholas J. Penington, ${ }^{1}$ John S. Kelly, ${ }^{2}$ and Aaron P. Fox ${ }^{1}$ \\ 'Department of Pharmacological and Physiological Sciences, The University of Chicago, Chicago, Illinois 60637 and \\ 2Department of Pharmacology, University of Edinburgh Medical School, Edinburgh EH89JZ, United Kingdom
}

Calcium currents and their modulation by 5-HT were studied using both whole-cell and single-channel patch-clamp techniques in acutely isolated adult rat dorsal raphe neurons. Evidence for three types of Ca channels ( $T, N, L$ ) was obtained in both whole-cell and single-channel experiments. Approximately $4 \%$ of the total high-threshold Ca current (Ltype) was sensitive to dihydropyridines (DHPs) while $\sim 40 \%$ of the $\mathrm{Ca}$ current ( $\mathrm{N}$-type) was sensitive to $\omega$-conotoxin $(\omega-$ CgTx). About $56 \%$ of the whole-cell current was insensitive to either DHPs or $\omega$-CgTx and may thus represent a different kind of $\mathrm{Ca}$ current. 5-HT reduced raphe neuron $\mathrm{Ca}$ currents by $\sim 50 \%$, while slowing activation. 5-HT inhibited both $\omega$-CgTx-sensitive and -insensitive Ca current. Inhibition by 5-HT was voltage dependent; prepulses to $+80 \mathrm{mV}$ lasting for $\mathbf{2 0}$ msec almost completely abolished the 5-HT-mediated inhibition. The voltage dependence of the response to 5-HT suggested that trains of action potentials might overcome the inhibition due to 5-HT. Trains of brief depolarizations were used to simulate action potentials; only about $5 \%$ of the 5-HT-induced inhibition was relieved by the trains. These results suggest that while large depolarizations could restore the Ca current inhibited by 5-HT, physiological stimuli, such as trains of action potentials, could not. The action of 5-HT was made irreversible by inclusion of GTP- $\gamma-S$ in the patch pipette, suggesting a G-protein mediation of the response to 5-HT. Second messenger pathways were activated to see if they played a role in the response to $5-\mathrm{HT}$, including protein kinase $A$, protein kinase $C$, and cGMP. dependent kinase; $\mathrm{H}-7$, a nonspecific kinase inhibitor, was used to test for kinase involvement. None of the second messenger systems mimicked the response to 5-HT. Cellattached recordings of single $\mathrm{Ca}$ channels were not affected by $5-\mathrm{HT}$ added to the bath outside the patch pipette. Taken together, these data suggest that the voltage-dependent action of 5-HT did not involve an easily diffusible second messenger, and the receptor, the G-protein, and the calcium channel may be tightly coupled. Inhibition may proceed via a direct interaction between G-proteins and the Ca channels.

Received Feb. 4, 1991; revised June 10, 1991; accepted June 24, 1991.

This work was supported in part by a Wellcome Trust postdoctoral research fellowship to N.J.P. and grant to J.S.K., and also by NIH, Klingenstein Fund, McKnight Foundation, Sloan Foundation, Whitaker Foundation, Brain Research Foundation, and Sprague Foundation awards to A.P.F.

Correspondence should be addressed to Nicholas J. Penington, The University of Chicago, Department of Pharmacological and Physiological Sciences, 947 East 58 th Street, Chicago, IL 60637.

Copyright @ 1991 Society for Neuroscience $0270-6474 / 91 / 113594-16 \$ 05.00 / 0$
The dorsal raphe (DR) nucleus is the largest group of 5-HTcontaining neurons in the rat CNS. In vivo, these neurons are spontaneously active (Trulson and Jacobs 1979), and presumably this activity is correlated with a tonic release of $5-\mathrm{HT}$. Changes in levels of 5-HT and subsequently of neurotransmission in the CNS can lead to many behavioral abnormalities in rats, including changes in locomotor activity, food intake, aggression, sexual behavior, and mood (Trulson and Jacobs, 1979).

DR neurons send inhibitory serotonergic collaterals to neighboring DR neurons (Wang and Aghajanian, 1977). Intracellular current-clamp recordings in slices containing the DR nucleus have shown that the 5-HT-mediated inhibition involved the activation of an inwardly rectifying $\mathrm{K}^{+}$current (Lakoski and Aghajanian, 1984; Rainnie et al., 1987; Williams et al., 1988). The response was mediated by the activation of $5-\mathrm{HT}_{1 \mathrm{~A}}$ receptors (Rainnie et al., 1987; Williams et al., 1988) and a pertussis toxin-sensitive GTP-binding protein (Innis et al., 1988). Similar responses to $5-\mathrm{HT}_{1 \mathrm{~A}}$ receptor activation have been observed in hippocampal as well as other neurons (Andrade and Nicoll, 1987; North et al., 1987).

Using acutely isolated DR neurons and patch-clamp techniques, 5-HT receptor activation has been shown to cause a large reduction in the $\mathrm{Ca}$ current accompanied by a marked slowing of the rate of activation (Penington and Kelly, 1990). In the above study, the inhibitory action of 5-HT was shown to be mimicked by 8 -hydroxy-(2-N,N-dipropylamino)-tetraline (8-OH-DPAT) and blocked by the $5-\mathrm{HT}_{1 \mathrm{~A}}$ antagonist NAN190 , and so the effect was probably mediated by a $5-\mathrm{HT}_{1 \mathrm{~A}}$ receptor subtype. In the present study, we have investigated the response to 5-HT to find out if there are any similarities to results observed with other neurotransmitters in peripheral neurons (Dunlap and Fischbach, 1981; Bean, 1989; Elmslie et al., 1990) where large depolarizations reversed the inhibition of calcium current caused by both noradrenaline and luteinizing hormone-releasing hormone (LHRH) (Bean, 1989; Elmslie et al., 1990). We have found that large depolarizations overcome the 5-HT-mediated inhibition of Ca currents in a fashion analogous to that observed with other transmitters in sympathetic neurons. On the basis of these studies, a model has been proposed in which it was suggested that in the absence of neurotransmitter, the majority of calcium channels dwell in a closed state from which they are "willing" to open upon depolarization (Bean, 1989). Inhibitory neurotransmitters, such as 5-HT, promote a second state from which the channels are "reluctant" to open when depolarized. Nevertheless, depolarization of the membrane potential can convert "reluctant" to "willing" channels. We have investigated the effects that simulated action po- 
tentials might have on "reluctant" Ca channels in order to resolve two questions. (1) Can changes in membrane potential occurring during an action potential overcome the inhibition induced by 5-HT? (2) If so, can any relief of inhibition produced by one action potential be "remembered" by subsequent action potentials in a train so that the relief summates? In view of the similarity of the effects of neurotransmitters that inhibit $\mathrm{Ca}$ currents in central and peripheral nerve preparations, it is possible that the results of this study may be applicable to other nerve cells in the brain.

The present study confirms the existence of $\mathrm{T}-, \mathrm{N}-$, and L-type Ca channel currents on DR neuron cell bodies, using direct single-channel measurements. The pharmacological profile of the different currents was obtained using BAY K 8644 , nimodipine, and $\omega$-conotoxin $(\omega-\mathrm{CgTx})$. DR neurons had a large component of current that was insensitive to either dihydropyridines (DHPs) or $\omega$-CgTx. An attempt was made to determine which current component was inhibited by 5-HT. The mechanism by which 5-HT inhibits DR neuron Ca current was also investigated, and the role of G-proteins and second messengers was examined. Experiments were also designed to test the possibility that the voltage-dependent inhibition of DR neuron $\mathrm{Ca}$ current was mediated by the direct interaction of $\mathrm{Ca}$ channels and G-proteins.

\section{Materials and Methods}

Three coronal slices $(500 \mu \mathrm{m})$ through the brainstem at the level of the dorsal raphe nucleus were prepared from young adult rats $(200-250 \mathrm{gm})$ in a conventional manner using a "vibroslice." The slices were placed in cold Ringer's solution containing (in $\mathrm{mM}$ ) $\mathrm{NaCl}, 119 ; \mathrm{KCl}, 5 ; \mathrm{MgCl}_{2}$, $2 ; \mathrm{CaCl}_{2}, 2 ; \mathrm{NaHCO}_{3}, 26 ; \mathrm{NaH}_{2} \mathrm{PO}_{4}, 1.2 ;$ and glucose, $11 ; \mathrm{pH} 7.3-7.4$ when bubbled with $95 \% \mathrm{O}_{2}, 5 \% \mathrm{CO}_{2}$. The slices were placed on an agar base, and a piece of gray matter $2 \times 2 \mathrm{~mm}$ containing the dorsal raphe nucleus was cut from immediately below the cerebral aqueduct. The pieces of tissue were then incubated in a 1,4-piperazinediethanesulfonic acid (PIPES) buffer solution containing $0.07 \%$ trypsin (Sigma type XI) under pure oxygen for $90 \mathrm{~min}$ according to the method of Kay and Wong (1987). The tissue was then triturated in Dulbecco's modified Eagle's medium, and the isolated cells were allowed to settle on a glass coverslip coated with concanavalin A. Within 5 min of plating, the cells were firmly anchored to the coated coverslip. Recordings were immediately carried out at room temperature $\left(22-25^{\circ} \mathrm{C}\right)$

Initial experiments designed to evaluate action potential waveform were carried out using a $\mathrm{K}^{+}$gluconate pipette solution ( $\mathrm{K}^{+}$Gluconate, $84 \mathrm{~mm}$; HEPES, $10 \mathrm{~mm}$; Mg-ATP, $2 \mathrm{~mm}$; KCl, $38 \mathrm{~mm}$; EGTA, $11 \mathrm{~mm}$ $\mathrm{KOH}, 33 \mathrm{~mm}$; $\mathrm{CaCl}_{2}, 1 \mathrm{~mm}$; GTP, $300 \mu \mathrm{M}$; pH 7.3 with $\mathrm{NaOH}$ ) and bathing solution $\mathrm{A}$, which contained (in $\mathrm{mM}$ ) $\mathrm{NaCl}, 147 ; \mathrm{KCl}, 2.5 ; \mathrm{CaCl}_{2}$ $2 ; \mathrm{MgCl}_{2}, 2$; glucosc, 10; HEPES, 20; $\mathrm{pH} 7.3$ with $\mathrm{NaOH}$. The experience of others, as well as ourselves (Huguenard and Alger, 1986; Kay and Wong, 1987) is that seals on acutely isolated adult neurons are unstable when using cesium chloride in the patch pipette. In contrast, when the pipettes contained the anions $\mathrm{HPO}_{4}^{-2}$ or $\mathrm{MeSO}_{3}$ this resulted in longlasting high-quality recordings. The pipette solution used in most experiments was a Tris phosphate-based solution containing tetraethylammonium chloride (TEA) to block outward currents (Tris- $\mathrm{PO}_{4}, 70$ mM; Trizma base 33-EGTA, $11 \mathrm{~mm}$; Mg-ATP, 2 mM; GTP, $300 \mu \mathrm{M}$ TEA, $40 \mathrm{~mm}$; $\mathrm{pH} 7.3$ with Trizma base). Calcium current rundown was less severe when using Tris phosphate pipette solutions (about $1.5 \%$ / min once it started, but sometimes the onset was delayed). Experiments performed using cesium chloride produced currents with a much faster rate of "rundown" (CsCl, $100 \mathrm{~mm}$; HEPES, $10 \mathrm{~mm}$; Mg-ATP, $2 \mathrm{~mm}$; EGTA, $10 \mathrm{~mm}$; GTP, $300 \mu \mathrm{M}$; pH 7.3 with $\mathrm{CsOH})$. Internal $\mathrm{Cs}^{+}$proved incompatible with a Tris buffer as a constituent of the solution precipitated on addition of $\mathrm{Cs}^{+}$.

The extracellular solution was continually perfused at a rate of about $2 \mathrm{ml} / \mathrm{min}$ into a bath containing about $1 \mathrm{ml}$ of recording solution. In order to eliminate the contribution of $\mathrm{Na}^{+}$ions to the inward current, $0.1 \mu \mathrm{M}$ TTX was added to all recording solutions. For whole-cell recording, seals were established in " 5 Ca Tyrode's" containing (in mM)
$\mathrm{NaCl}, 135 ; \mathrm{HEPES}, 20$; glucose, $10 ; \mathrm{CaCl}_{2}, 5 ; \mathrm{KCl}, 1 ; \mathrm{MgCl}_{2}, 1$. The external recording solution was designed to isolate calcium channel currents (carried by $\mathrm{Ba}^{2+}$ ) and contained (in mM): TEA-Cl, 135; $\mathrm{BaCl}_{2}$, 5; HEPES, 20; glucose, 10; $\mathrm{pH} 7.3$ with TEA-OH. The osmolarity of the pipette solution was adjusted with sucrose to be 20 mOsm hypoosomotic to the recording solution ( $300 \mathrm{mOsm} /$ liter). This usually prevented cell swelling. Drugs were dissolved in the extracellular solution and added to the perfusate, or in the case of dihydropyridines and $\omega-\mathrm{CgTx}$ they were added directly to the bath by pipette near the cell under study after the bath flow was halted, achieving a known final concentration. For experiments involving nimodipine and BAY K 8644, the final concentration of ethanol in the bath was $0.01 \%$. All manipulations involving nimodipine and BAY K 8644 were carried out in the dark to avoid degradation due to photosensitivity.

Neurons with truncated dendrites and a cell soma with one dimension of at least $20 \mu \mathrm{m}$ were voltage clamped using an Axopatch 1c patchclamp amplifier in the whole-cell configuration (Hamill et al., 1981). Electrodes were pulled from soda-lime glass capillary tubes (Scientific Products), were coated with Sylgard, and ranged in resistance from 1.8 to $2.5 \mathrm{M}$. The series resistance circuit of the amplifier was used to compensate $\approx 80 \%$ of the apparent series resistance. Clamp setting time was typically less than $1 \mathrm{msec}$. In TEA, the seal resistance was often greater than $5 \mathrm{G} \Omega$. Leak and capacitance were subtracted from the current records. Leak sweeps consisted of 16 hyperpolarizing steps of $10 \mathrm{mV}$, which were then averaged. The leak sweep currents were scaled to the appropriate size and then subtracted from the individual current records. Leak sweeps were obtained at regular periods during the experiment. The voltage-clamp data were filtered at $3 \mathrm{kHz}$ and then digitized at 100 or $200 \mu \mathrm{sec}$ per point. Voltage protocols were generated and analyzed by an IBM PC 386 clone using the AXOBAsic 1 patchclamp software, and the resultant data were written to disk for analysis off line.

Single-channel experiments. Single-channel experiments were performed using the cell-attached patch mode of recording. The pipette contained (in mM) $\mathrm{BaCl}_{2}, 90$; HEPES, $10 ; \mathrm{CsCl}, 15$; TEA-Cl, 15; pH 7.4 with $\mathrm{Ba}(\mathrm{OH})_{2}$. TEA and $\mathrm{Cs}^{+}$were included in the pipette in order to block $\mathrm{K}^{+}$channels in the patch. The bath solution contained (in $\mathrm{mM}$ ) $\mathrm{K}^{+}$aspartate, $140 ; \mathrm{K}^{+}$-EGTA, 10; $\mathrm{MgCl}, 1$; HEPES, 10; $\mathrm{pH} 7.4$ with $\mathrm{KOH}$. This external solution has been shown to zero the resting potential of isolated neurons (Fox et al., 1987b). For the leak subtraction of singlechannel data, sweeps were recorded in which no channels opened or records were obtained using steps to potentials too negative for channel opening. Leak subtraction consisted of a veraging leak sweeps by taking a moving average closest in time to the data. Single-channel data were filtered using an eight-pole Bessel filter with a corner frequency of 1 $\mathrm{kHz}$. The data were usually sampled at $200 \mu \mathrm{sec}$ intervals.

\section{Results}

The electrical properties of $D R$ neurons remained intact after enzymatic dissociation

Current-clamp recordings from acutely dissociated DR neurons (using a patch pipette that contained a $\mathrm{K}^{+}$-gluconate internal solution; see Materials and Methods) resembled those recorded in the slice preparation (Crunelli et al., 1983; Vandermaelen and Aghajanian, 1983). The membrane potential ranged from -40 to $-60 \mathrm{mV}$. Overshooting action potentials $(80-100 \mathrm{mV})$ occurred spontaneously (Fig. $1 A$ ) and could be elicited by depolarizations from $-60 \mathrm{mV}$ (Fig. $1 B$ ). On an expanded time base, the DR neuron action potential falling phase showed a distinct shoulder (Fig. 1C) followed by an afterhyperpolarization. TTX $(0.2 \mu \mathrm{M})$ abolished the fast component of the action potential and uncovered both low- and high-threshold spikes, probably carried by $\mathrm{Ca}^{2+}$ ions. The high-threshold $\mathrm{Ca}$ spike was evoked by depolarizations greater than those required to initiate the TTX-sensitive $\mathrm{Na}^{+}$component (Fig. 1D). The low-threshold Ca spike was inactivated by membrane holding potentials positive to $-50 \mathrm{mV}$. The two types of $\mathrm{DR}$ neuron $\mathrm{Ca}$ action potentials are somewhat similar to those previously described in inferior olivary neurons (Llinas and Yarom, 1981). 
A

B

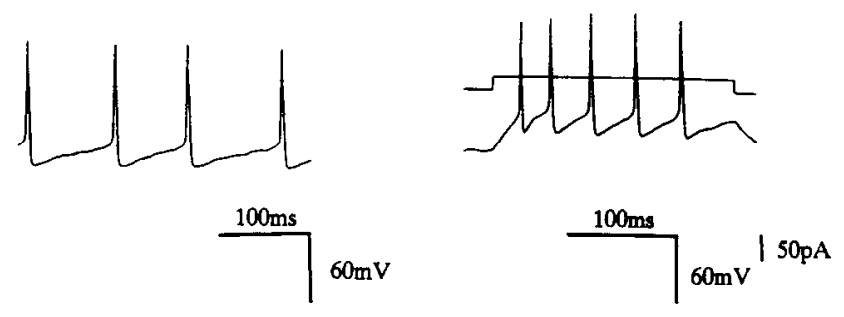

$\mathrm{C}$

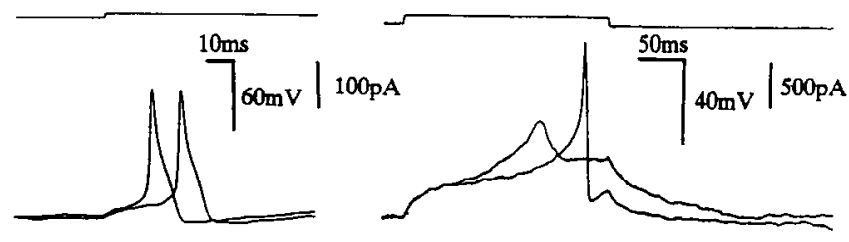

Figure 1. Representative voltage records from acutely isolated DR neurons obtained under current clamp. $A$, The cells often exhibited spontaneous activity at the zero current potential $\mathrm{Vm} . B$ is a record from the same cell when the spontaneous firing had temporarily ceased. DC current injection ( $30 \mathrm{pA}$ ) elicited repetitive firing with some accommodation of the spike frequency. $C$, Typical action potentials consisted of an initiating ramp of depolarization, a shoulder upon repolarization, and an afterhyperpolarization. $D$, Record from another cell bathed in TTX $(0.2 \mu \mathrm{M})$. A depolarization from $-70 \mathrm{mV}$ triggered a slow, lowthreshold action potential that was capable of activating a high-threshold spike. These potentials were completely blocked by $20 \mu \mathrm{M} \mathrm{Cd^{2+ }} . \mathrm{K}^{+}$gluconate was used in the patch pipette (see Materials and Methods).

\section{Characterization of $D R$ neuron Ca currents}

Figure 2 shows representative whole-cell currents recorded under conditions that suppressed $\mathrm{Na}^{+}$and $\mathrm{K}^{+}$current (see Materials and Methods). With $5 \mathrm{mM} \mathrm{Ba}^{2+}$ as the charge carrier, DR neurons exhibited robust inward calcium channel currents (which frequently measured $3.5 \mathrm{nA}$ ). Weak depolarizations from a holding potential of $-80 \mathrm{mV}$ (Fig. $2 A$ ) elicited a small, rapidly decaying current with the characteristics of the "T-type" $\mathrm{Ca}$ current previously described in cultured chick dorsal root ganglion (DRG) neurons (Carbone and Lux, 1984; Fox et al., 1987a). Stronger depolarizations (Fig. $2 B$ ) evoked a much larger inward current, peaking at $-10 \mathrm{mV}$. If this component contained significant $\mathrm{N}$-type $\mathrm{Ca}$ current, the rate of current decay was slower than that observed in chick DRG neurons but faster than that observed in cultured sympathetic neurons (Fox et al., 1987a; Hirning et al., 1988). Changing the holding potential (hp) from -100 to $-50 \mathrm{mV}$ (Fig. $2 B$ ) decreased the current amplitude by $61.6 \pm 4.6 \%$ (SEM; $n=7$ ), possibly indicating the existence of a sizable component of $\mathrm{N}$-like $\mathrm{Ca}$ current that was inactivated by positive voltages. The rate of current inactivation was almost negligible over the duration of the $150 \mathrm{msec}$ test pulse. DR neuron $\mathrm{Ca}$ currents were similar to other N-type $\mathrm{Ca}$ channel currents in that it took the current many seconds to reach a steady state value upon changing the membrane holding potential (Plummer et al., 1989; Sah et al., 1989). A typical currentvoltage plot, obtained from $h p=-100 \mathrm{mV}$, is illustrated in Figure $2 C$.

The only way to resolve the possibility that the components of current seen in the whole-cell recordings correspond to different calcium channels was to determine whether similar activation parameters would evoke separate classes of single-chan- nel activity. Voltage protocols reflect the different ionic conditions for the single-channel experiments. While each panel in Figure $3 A$ shows single-channel activity representing primarily one type of Ca channel, all possible combinations of activity were observed in 33 patches from different cells. The left panel shows the large-conductance ( $23 \mathrm{pS}$ ) L-type calcium channel openings observed in the presence of BAY K $8644(1 \mu \mathrm{M})$, a DHP Ca channel agonist that promotes long-lived openings of $\mathrm{L}$-type $\mathrm{Ca}$ channels (Hess et al., 1984; Kokubun and Reuter, 1984; Nowycky et al., 1985b). The activity was elicited from $h p=-20 \mathrm{mV}$. The middle panel shows unitary activity (also at $-20 \mathrm{mV}$ ) of a channel with a conductance of $15 \mathrm{pS}$, intermediate between $\mathrm{L}$ - and T-type and similar to the $\mathrm{N}$-type channels described in DRG neurons (Fox et al., 1987b). The data in the left and middle panels (Fig. 3) were recorded from the same patch. At a depolarized $\mathrm{hp}=-20 \mathrm{mV}$ (left panel), only $23 \mathrm{pS}$ (L) channel activity was manifested, suggesting that the $15 \mathrm{pS}(\mathrm{N})$ channel had inactivated. At $-20 \mathrm{mV}$ after a step from $\mathrm{hp}=-80 \mathrm{mV}$ (middle panel), both 23 and $15 \mathrm{pS}$ activity was observed, but records showing predominantly $15 \mathrm{pS}$ activity are plotted. T-type $\mathrm{Ca}$ channels could be readily observed in isolation by using test depolarizations too small to activate other channel types (Fig. $3 A$, right panel). The $\mathrm{T}$-type $\mathrm{Ca}$ channels had a slope conductance of $8 \mathrm{pS}$, similar to those in DRG neurons and heart (Nilius et al., 1985; Nowycky et al., 1985a). T-channel openings clustered at the beginning of the depolarization, indicating that they would give rise to a decaying whole-cell current. Indeed, ensemble averages (not shown) of $\mathrm{T}$-channel activity had inactivating waveforms indistinguishable from the whole cell $T$ currents shown in Figure 2. T-channel openings could not be evoked at depolarized holding potentials $(\geq-50 \mathrm{mV}$ ). Figure $3 B$ plots the single-channel current-voltage plots for the three types of $\mathrm{Ca}$ channels illustrated in Figure $3 \mathrm{~A}$. Amplitude histograms confirmed the presence of three different conductance levels (not shown). No evidence for a fourth type of $\mathrm{Ca}$ channel was detected in unitary amplitude data.

\section{Effects of DHP antagonists}

Figure $4 A$ shows a plot of peak current as a function of time. $\mathrm{Ca}$ current was clicited once every $20 \mathrm{sec}$ by a test depolarization to $-10 \mathrm{mV}$ from $\mathrm{hp}=-50 \mathrm{mV}$. The peak current recorded for each depolarization is plotted as a solid square in the figure. At the first arrow, nimodipine $(1 \mu \mathrm{M})$ was introduced into the bath, producing a small (19\%) decrease in the Ca current. The concentration of nimodipine in the bath was increased to $2 \mu \mathrm{M}$ at the second arrow without further effect. The inset shows wholecell calcium current activated by a voltage step to $-10 \mathrm{mV}$ from $\mathrm{hp}=-100 \mathrm{mV}$; superimposed on this is a current elicited from $\mathrm{hp}=-50 \mathrm{mV}, 54 \%$ smaller than the current at $-100 \mathrm{mV}$. DHPs antagonize Ca currents more efficiently from depolarized holding potentials (Bean, 1984; Sanguinetti and Kass, 1984). The combination of $1 \mu \mathrm{M}$ nimodipine and depolarized holding potential $(-50 \mathrm{mV})$ used in the experiment depicted in Figure $4 A$ should have been sufficient to produce a maximal blockade of L-channels. In this experiment, if all of the L-type channels were reprimed at $-50 \mathrm{mV}$, and if they werc all blocked by nimodipine, then only about $8.7 \%$ of the total current at $\mathrm{hp}=$ $-100 \mathrm{mV}$ would be L-type (estimated by using the fact that $54 \%$ of the Ca current was inactivated when the holding potential was changed from -100 to $-50 \mathrm{mV}$ ). Nimodipine was never able to produce a large block of the total current elicited from $-50 \mathrm{mV}$ [average inhibition, $9.7 \%(n=6)$, which yields a cal- 
A
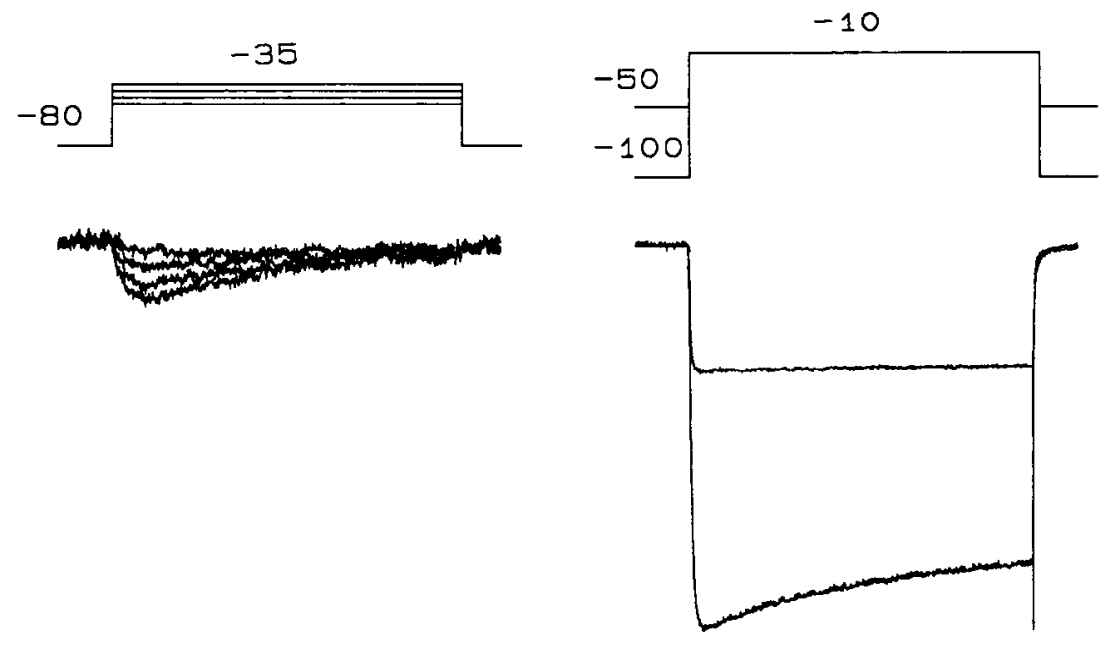

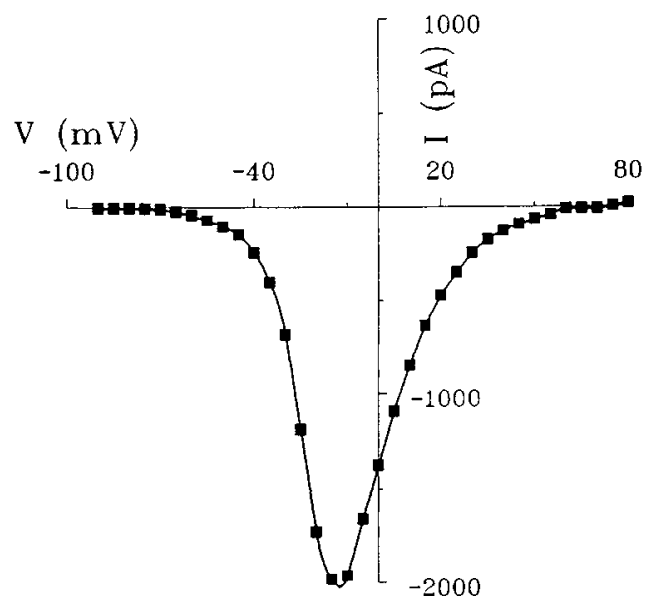

B

C
$500 \mathrm{pA}$ 
A

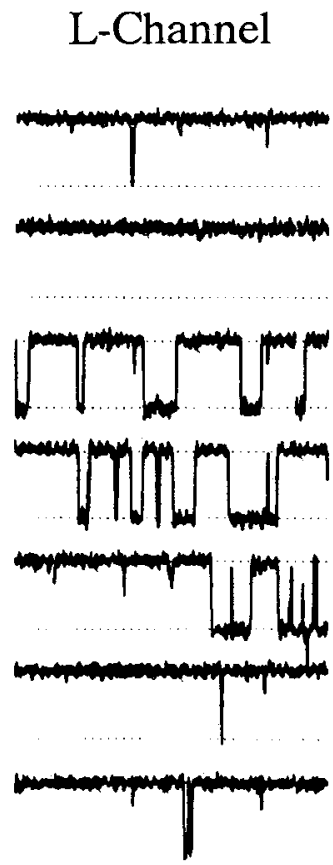

N-Channel

T-Channel

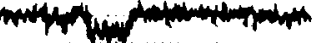

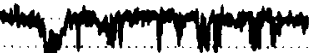
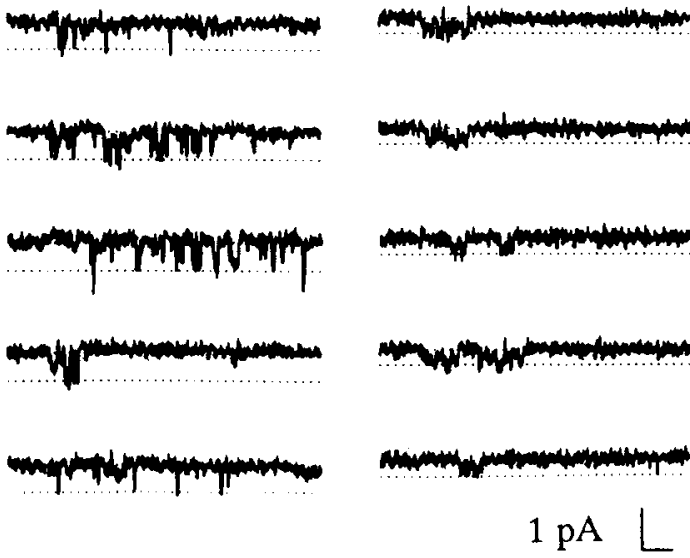

$20 \mathrm{~ms}$
Figure 3. DR neurons had three types of unitary activity. Recordings were made from on-cell patches with $90 \mathrm{~mm}$ $\mathrm{BaCl}_{2}$ in the patch pipette. $A:$ Left, L-type channel activity obtained after setting the patch potential to $-20 \mathrm{mV}$, in the presence of $1 \mu \mathrm{M}$ BAY K 8644 . Middle, Data from the same patch after changing to $\mathrm{hp}=-80 \mathrm{mV}$; the test potential was stepped to $-20 \mathrm{mV}$. Only sweeps showing little L-type activity are plotted. Right, Records taken from another patch to illustrate $\mathrm{T}$-channel openings also at $-20 \mathrm{mV}(\mathrm{hp}=-100$ $\mathrm{mV}$ ). $B$ plots the single-channel current-voltage relationship for each of the channel types. Each point represents the average of $\sim 30$ measurements of channel openings at the relevant test voltage, taken from two patches. All possible combinations of these three conductances were observed in different patches.

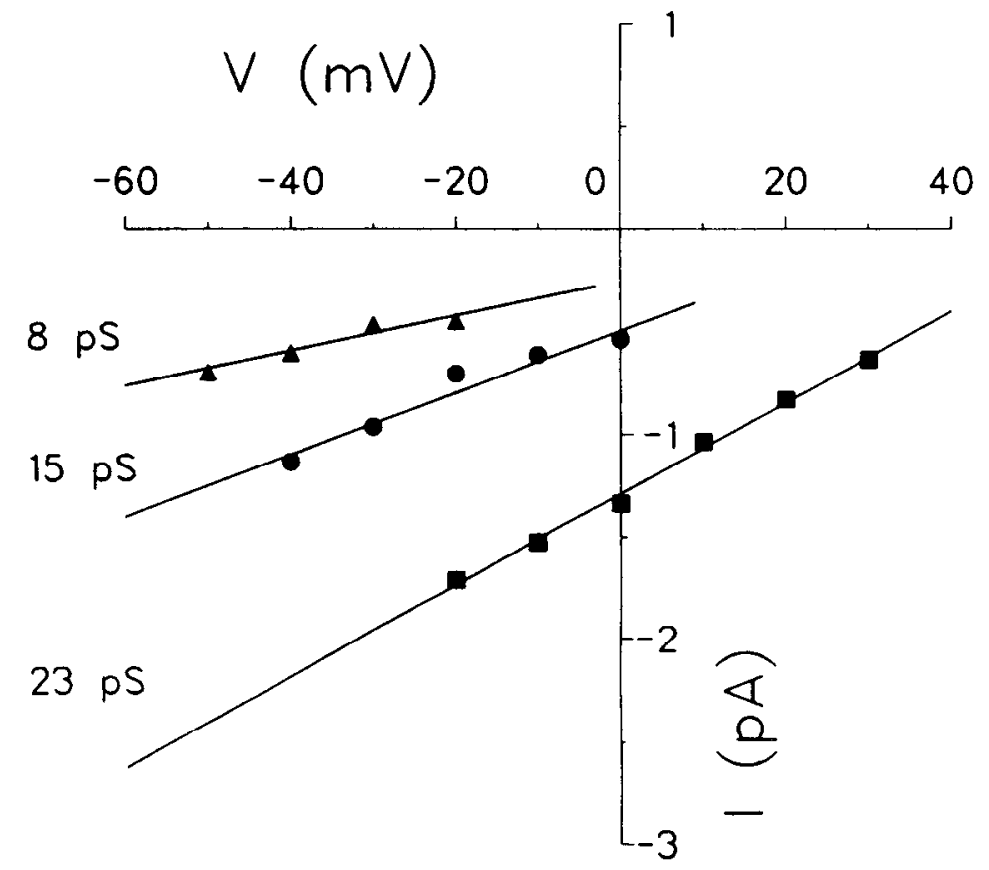

showed that T-channels were unaffected (Penington and Kelly, 1990).

As only a small fraction of the whole-cell current was DHP sensitive, the results shown in Figure 6 suggest that the primary target for 5-HT modulation was $\omega$-CgTx-sensitive $\mathrm{N}$-type $\mathrm{Ca}$ channels, the $\omega$-CgTx- and DHP-insensitive current, or both. $\mathrm{N}$-type $\mathrm{Ca}$ channels have previously been shown to be quite sensitive to changes in holding potential (Fox et al., 1987b). We decided to explore the question of which component of current was inhibited by 5 -HT by examining the effect at different hold- ing potentials. If 5-HT preferentially modulated a subset of the channels that were inactivated by positive holding potentials, then one would expect 5-HT to be less effective or completely inactive from $\mathrm{hp}=\cdots 50 \mathrm{mV}$. Responses to the application of $5-\mathrm{HT}$ at $\mathrm{hp}=-100$ and $\mathrm{hp}=-50 \mathrm{mV}$ are illustrated in Figure $6 \mathrm{~A}$. Changing the holding potential from -100 to $-50 \mathrm{mV}$ reduced the current to $54 \%$ of control. Nevertheless, at hp $=$ $-50 \mathrm{mV} 5$-HT was still able to inhibit the remaining calcium current by $58.1 \pm 4.3 \%( \pm \mathrm{SEM} ; n=5)$. The results obtained from $\mathrm{hp}=-50 \mathrm{mV}$ were not statistically different from those 

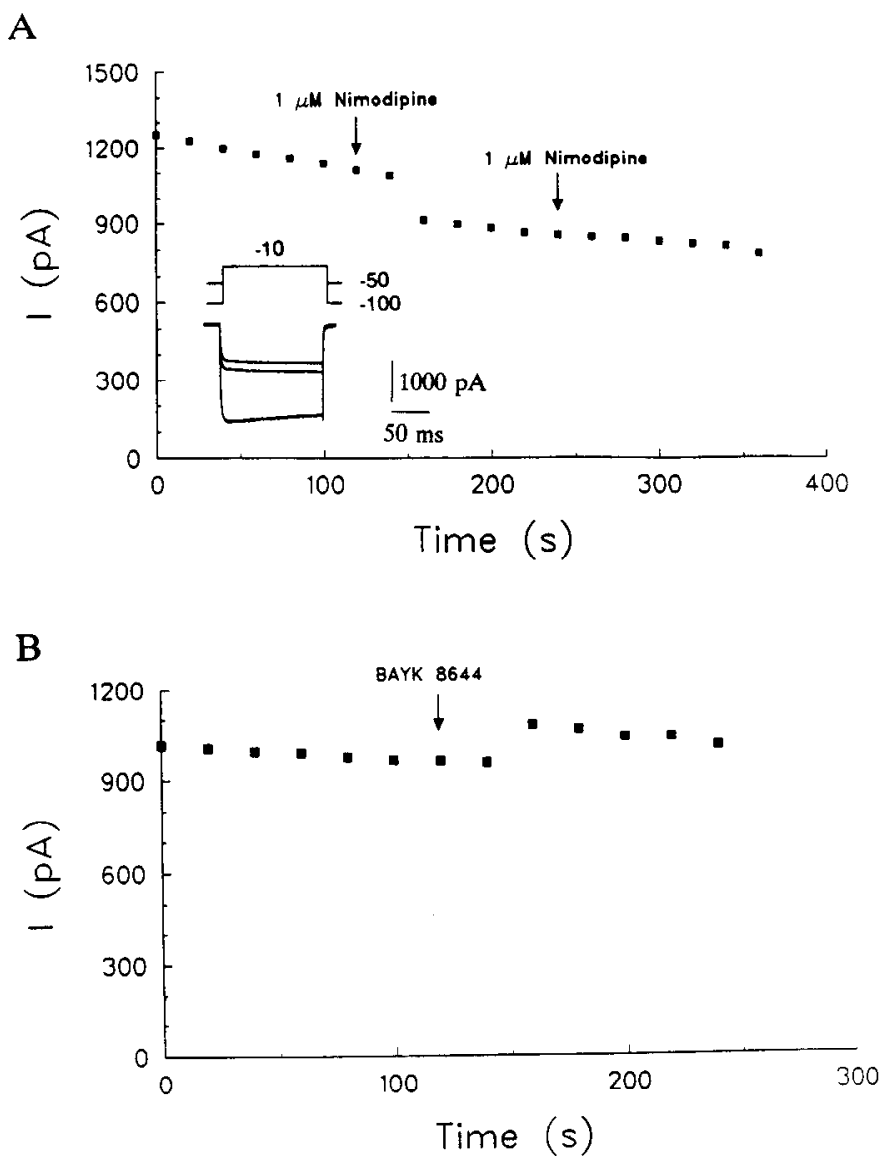

Figure 4. Effect of DHP agonists and antagonists on DR neuron Ca currents. $A$ plots peak $\mathrm{Ca}$ current against time. The cell was depolarized to $-10 \mathrm{mV}$ from $\mathrm{hp}=-50 \mathrm{mV}$ every $20 \mathrm{sec}$. Nimodipine (final concentration, $1 \mu \mathrm{M}$ ) was added to the bath by pipette at the arrows (see Materials and Methods). Of the current elicited with this protocol, $19 \%$ was DHP sensitive. The inset illustrates current elicited by a test depolarization to $-10 \mathrm{mV}$ from $\mathrm{hp}=-100 \mathrm{mV}$. After changing $\mathrm{hp}=$ $-50 \mathrm{mV}$, the next smallest current was recorded. The smallest of the superimposed currents occurred just after the addition of nimodipine. $B$, Plot of peak current versus time showing that the addition of $1 \mu \mathrm{M}$ BAY K 8644 caused an $11 \%$ increase in peak Ca current. Ca current was elicited by test depolarizations to $-10 \mathrm{mV}$ every $20 \mathrm{sec}$ from hp $=-100 \mathrm{mV}$.

obtained at $\mathrm{hp}=-100 \mathrm{mV}$; each cell was tested with $5-\mathrm{HT}$ at the two holding potentials. After scaling, the Ca current elicited from $h p=-50 \mathrm{mV}$, in $5-\mathrm{HT}$, could be superimposed with the Ca current elicited from $h p=-100 \mathrm{mV}$, again in 5-HT. A histogram showing the effectiveness of 5-HT at inhibiting the Ca current elicited from $\mathrm{hp}=-100 \mathrm{mV}$ and $-50 \mathrm{mV}$ is illustrated in Figure $6 B$. The proportion of 5-HT-sensitive current was about the same at the two holding potentials.

$\omega-\mathrm{CgTx}$ was used to dissect $\mathrm{N}$-type $\mathrm{Ca}$ current pharmacologically to determine if this component was being inhibited by 5-HT. An example of such an experiment is shown in Figure 7. If 5-HT preferentially modulated a subset of channels that were sensitive to $\omega$-CgTx, then one would expect diminished 5-HT responses after treatment of the cells with the toxin. Figure $7 A$ shows that 5 -HT was still capable of producing a $38 \%$ inhibition of whole-cell current after $\omega$-CgTx $(1 \mu \mathrm{M})$ treatment of this DR neuron. The histogram in Figure $7 B$ shows that in the control conditions 5 -HT (10 $\mu \mathrm{M})$ inhibited peak Ca current by $49.3 \pm 3 \%( \pm \mathrm{SEM} ; n=112)$ before $\omega-\mathrm{CgTx}$ treatment and 37.9

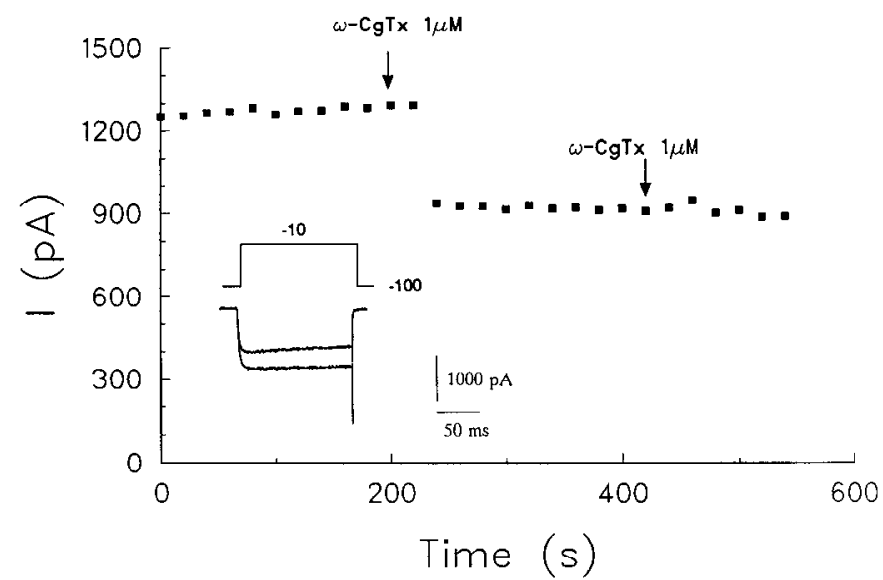

Figure 5. $\omega-\mathrm{CgTx}$ inhibition of a DR whole-cell Ca current. Plot of peak Ca current versus time; $\omega$-CgTx $(1 \mu \mathrm{M})$ was added at the arrow. In this experiment, $\sim 28 \%$ of the current was inhibited (currents shown in the inset). At the second arrow the concentration of $\omega-\mathrm{CgTx}$ in the bath was increased to $2 \mu \mathrm{M}$. The cell was depolarized to $-10 \mathrm{mV}$ from $\mathrm{hp}$ $=-100 \mathrm{mV}$ once very $20 \mathrm{sec}$. No recovery of current was observed on washing with toxin-free solution.

$\pm 4.4 \%( \pm \mathrm{SEM} ; n-5)$ after treatment. On average, the combination of $\omega-\mathrm{CgTx}$ and $5-\mathrm{HT}$ produced a $69 \%$ inhibition of the total $\mathrm{Ca}$ current. If the effects of $5-\mathrm{HT}$ and $\omega$-CgTx were completely additive, one would expect a $90 \%$ reduction in current $(\omega-\mathrm{CgTx}$ reduced the DR neuron Ca currents by an average $41 \%$, while $5-\mathrm{HT}$ reduced the Ca current by $49 \%$ ). Therefore, it seems likely that 5-HT targets a greater proportion of DR neuron $\mathrm{Ca}$ channels than those inhibited by $\omega-\mathrm{CgTx}$ but that $\omega-\mathrm{CgTx}-$ sensitive N-channels are a site for the action of 5-HT. In agreement with this conclusion is the observation that the magnitude of $\mathrm{Ca}$ current inhibited by 5-HT was always smaller after the application of $\omega-\mathrm{CgTx}$.

\section{Voltage dependence of 5-HT-mediated inhibition of $D R$ neuron Ca currents}

Figure 8 shows that the 5-HT-mediated inhibition of DR neuron $\mathrm{Ca}$ currents exhibited voltage dependence. Figure $8 \mathrm{~A}$ shows whole-cell Ca currents elicited from $\mathrm{hp}=-100 \mathrm{mV}$ by depolarizations to a variety of test potentials, obtained in the absence and presence (labeled "*”) of 5-HT $(10 \mu \mathrm{M})$. 5-HT had its greatest effect at potentials near $-10 \mathrm{mV}$. At more depolarized potentials (e.g., +30 and $+40 \mathrm{mV}$ ), 5-HT had little effect on the Ca currents. Figure $8 B$ shows plots of peak current versus membrane potential obtained in the presence and absence (isochronally) of 5-HT. The figure clearly illustrates the voltage-dependent nature of the inhibition by 5-HT. In this cell, the calcium channel current peak occurred $7.3 \mathrm{msec}$ after depolarizing the cell to $-10 \mathrm{mV}$ but took $98.7 \mathrm{msec}$ in the presence of $5-\mathrm{HT}$. In contrast, at $+30 \mathrm{mV}$ the current peaked $3.4 \mathrm{msec}$ after the depolarization under control conditions and after $4.6 \mathrm{msec}$ in the presence of 5-HT. Thus, 5-HT produces minimal slowing of $\mathrm{Ca}$ current activation at $+30 \mathrm{mV}$. A similar voltage dependence was obtained from $\mathrm{hp}=-60 \mathrm{mV}$ (not shown).

Because the effects of 5-HT were overcome at positive potentials, we investigated whether prepulses could suppress the 5-HT-mediated inhibition during a subsequent test pulse. Figure $9 A$ shows the inhibition induced by $5-\mathrm{HT}(10 \mu \mathrm{M})$ in this DR neuron. Figure $9 B$ superimposes currents recorded during 
A
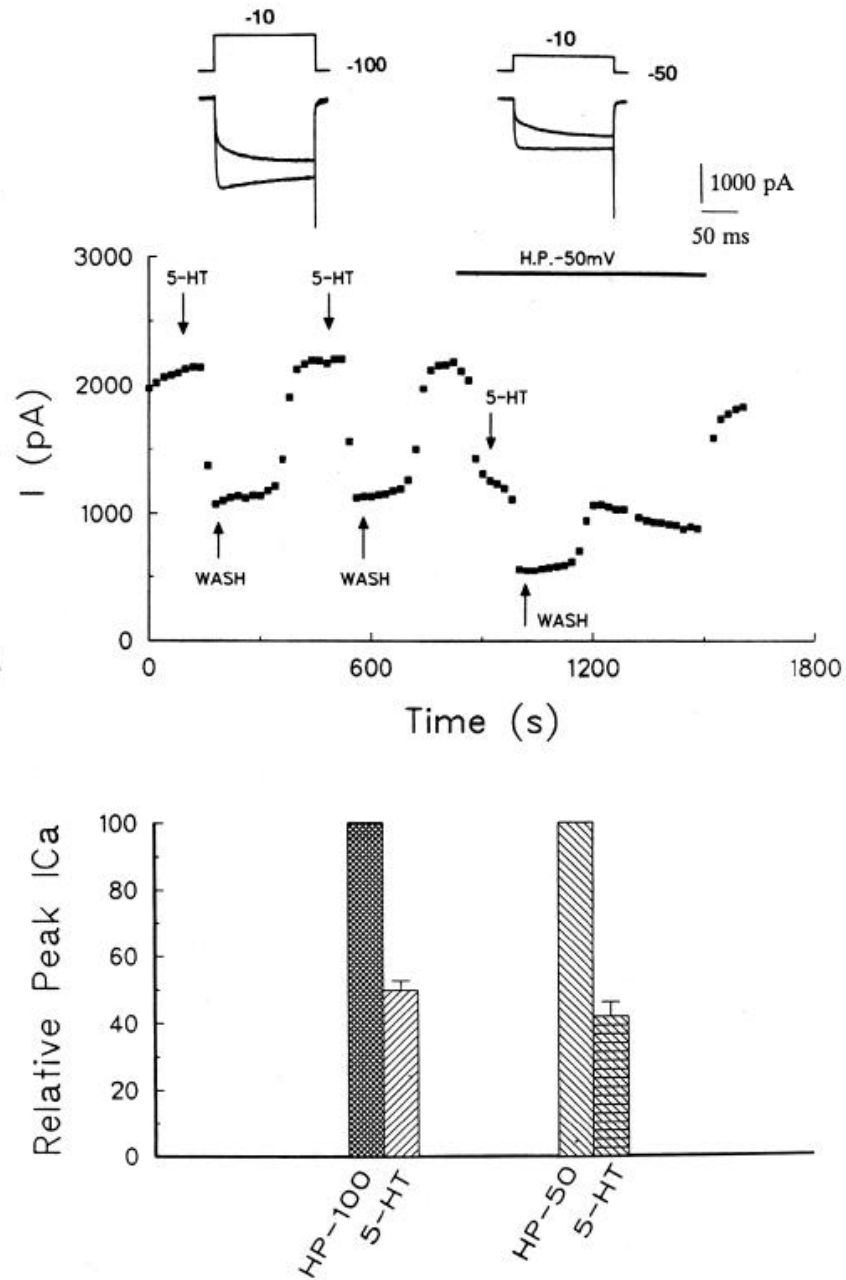

Figure 6. Holding potential independence of 5-HT action in the range of -100 to $-50 \mathrm{mV}$. $A$, Plot of early current versus time; 5 -HT (10 $\mu \mathrm{M})$ produced its characteristic inhibition of $\mathrm{Ca}$ current as the cell was depolarized from $\mathrm{hp}=-100 \mathrm{mV}$ to $-10 \mathrm{mV}$ every $20 \mathrm{sec}$. Changing to $\mathrm{hp}=-50 \mathrm{mV}$ but keeping the test potential at $-10 \mathrm{mV}$ inactivated $\sim 46 \%$ of the Ca current. When 5-HT $(10 \mu \mathrm{M})$ was reintroduced, about $46 \%$ of the early current was inhibited (early Ca currents were recorded by determining the time of peak current in 5-HT-free solutions and then measuring the current in 5-HT isochronally). The inset shows currents recorded under these conditions. $B$, Average responses to 5-HT at $\mathrm{hp}=-100 \mathrm{mV}$ and $-50 \mathrm{mV}$ as percent inhibition of $\mathrm{Ca}$ current normalized to the size of the control Ca current.

two test depolarizations, obtained in the absence of 5-HT, one preceded by a prepulse and the other not, illustrating that prepulses did not significantly alter DR neuron Ca currents (at hp $=-60 \mathrm{mV}$ ) unless 5 -HT was present [prepulses to $+80 \mathrm{mV}$ increased the $\mathrm{Ca}$ current during the test pulse by $5.8 \pm 2.2 \%$ $( \pm$ SEM; $n=12)$ in the absence of 5 -HT]. Figure $9 C$ shows that depolarizing prepulses were able to relieve the inhibition produced by 5 -HT during a test pulse. Both traces were elicited by depolarizing the cell to $-10 \mathrm{mV}$ from $\mathrm{hp}=-60 \mathrm{mV}$ (a holding potential close to the usual resting potential of DR neurons) in the presence of 5-HT; the larger current was preceded by a prepulse to $+80 \mathrm{mV}$ lasting for $100 \mathrm{msec}$. The current record with no prepulse showed the characteristic 5-HT-induced slowing of activation, while the trace preceded by the prepulse resembled currents obtained in the absence of 5-HT (Fig. 9B). In 12 cells, $75.5 \pm 6.4 \%( \pm$ SEM) of the inhibition produced by
A

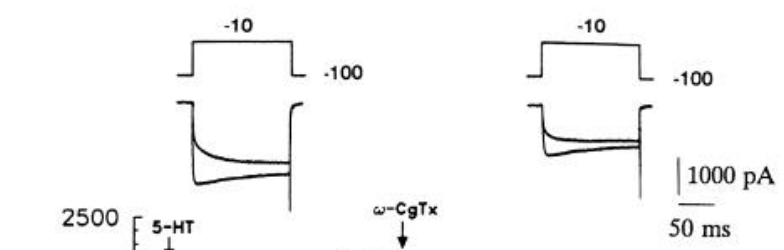

B

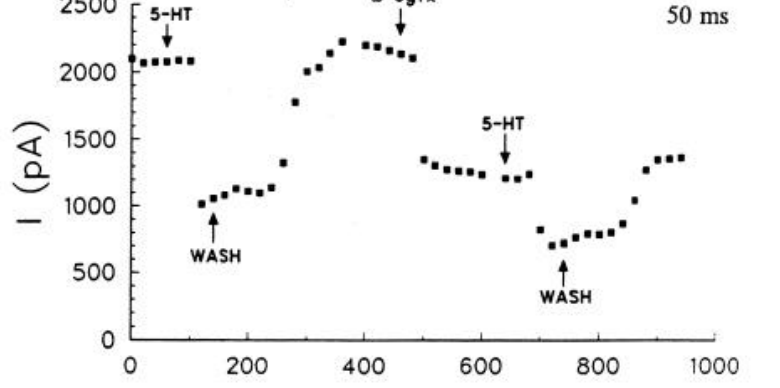

B Time (s)

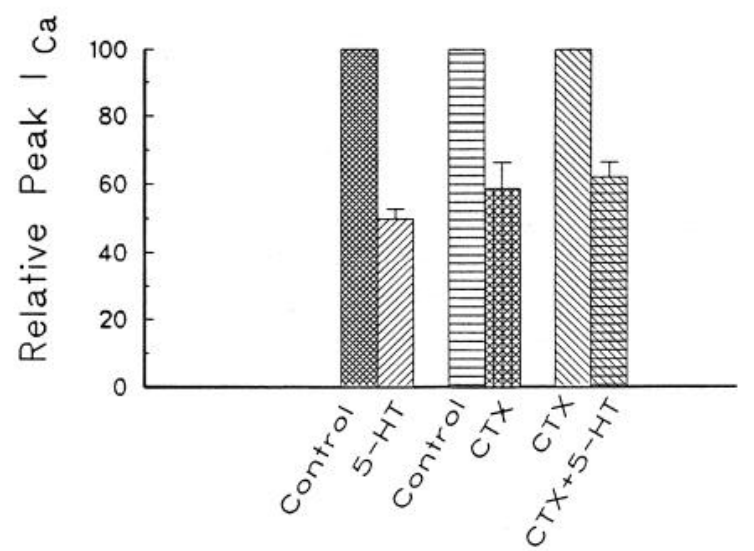

Figure 7. $\omega-\mathrm{CgTx}$ blocked only a fraction of the 5-HT-sensitive Ca current in DR neurons. $A$, Plot of early $\mathrm{Ca}$ current versus time showing a typical 5-HT $(10 \mu \mathrm{M})$ response (53\% of Ca current inhibited). The cell was depolarized to $-10 \mathrm{mV}$ from $\mathrm{hp}=-100 \mathrm{mV}$ once every $20 \mathrm{sec}$. $\omega-\operatorname{CgTx}(1 \mu \mathrm{M})$ was introduced as indicated in the figure, producing a $37 \%$ inhibition of the Ca current. Addition of $10 \mu \mathrm{M} 5-\mathrm{HT}$ produced a $38 \%$ inhibition of the remaining early $\mathrm{Ca}$ current. $B$, Average responses of DR neurons to 5-HT and $\omega-\mathrm{CgTx}$ in nine cells. The middle two bars show the effect of $\omega$-CgTx in five cells as percent inhibition normalized to the size of the control Ca current. $\omega$-CgTx inhibited control Ca current by $41.3 \pm 8 \%$. The last two bars illustrate the effect of 5 -HT $(10 \mu \mathrm{M})$ on the current in the presence of $\omega-\mathrm{CgTx}$. The current in the presence of $\omega-\mathrm{CgTx}$ was normalized to $100 \%$. 5-HT was still capable of inhibiting $37.9 \pm 4.4 \%$ of Ca current after $\omega$-CgTx treatment.

5 -HT was relieved by the use of the prepulse to $+80 \mathrm{mV}$. Figure $9 D$ compares $\mathrm{Ca}$ currents obtained in the presence of 5-HT after a prepulse to $\mathrm{Ca}$ currents obtained in drug-free conditions with no prepulse. The currents were quite similar (in two experiments they were identical). Prepulses to $+80 \mathrm{mV}$ lasting only $20 \mathrm{msec}$ were capable of reversing most of the 5-HT-mediated inhibition.

When activated by sensory input, DR neurons cannot fire faster than about 7 spikes/sec (Heym et al., 1982). This suggests that if an action potential were able to relieve the 5-HT inhibition occurring in subsequent action potentials, part of the voltage-dependent relief must last for at least $140 \mathrm{msec}$. Figure $9 E$ examines the time course of recovery from relief of inhibition by 5 -HT. Using a prepulse paradigm to $+80 \mathrm{mV}$ to relieve the inhibition by 5 -HT, the interval between the pre- and test pulses 
A

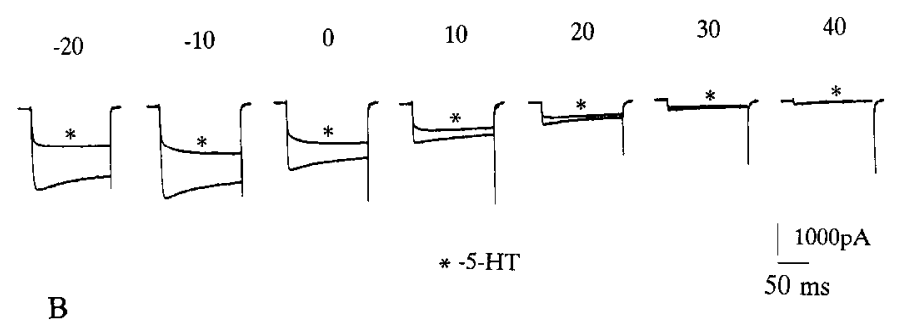

B

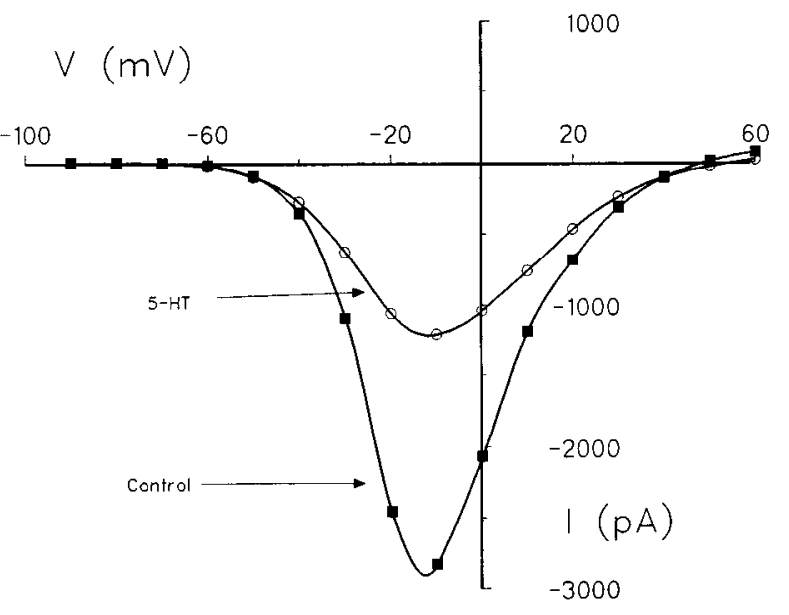

Figure 8. A, Voltage dependence of the 5-HT-mediated inhibition of $\mathrm{Ca}$ currents in acutely isolated DR neurons. Leak-subtracted calcium currents shown were elicited from $\mathrm{hp}=-100 \mathrm{mV}$ by depolarizations to the potentials indicated. Current traces marked with an asterisk were obtained in the presence of $10 \mu \mathrm{M}$ 5-HT. $B$, Peak current plottcd as a function of membrane potential $(I / V)$ in presence and absence of 5-HT $(10 \mu \mathrm{M})$.

was varied between 10 and $200 \mathrm{msec}$. Figure $9 E$ plots the percentage of relief from 5-HT inhibition as a function of the interval between prepulse and test pulse. The data are well fit by the sum of two exponentials $\left(\tau_{1}=20 \mathrm{msec}\right.$, and $\tau_{2}=145 \mathrm{msec}$; in four experiments the averages were $\tau_{1}=13.9 \mathrm{msec}$ and $\tau_{2}=$ $123 \mathrm{msec}$ ). Even $140 \mathrm{msec}$ after the prepulse there was still some relief from inhibition by $5-\mathrm{HT}$, suggesting that the effects of voltage were "remembered" for a period of time after the prepulse terminated.

The peak membrane potential attained during a DR neuron action potential, lasting about $1 \mathrm{msec}$, is between +15 and +20 $\mathrm{mV}$, due to activation of Na channels. In DR neurons, there is also a pronounced shoulder to the repolarizing phase of the action potential, which reflects a $\mathrm{Ca}$ channel component (Fig. 1C). Could the potentials reached by the early $\mathrm{Na}^{+}$-dependent component act as a prepulse to relieve 5-HT inhibition that occurs during the later $\mathrm{Ca}$-dependent shoulder? To answer this question, a voltage-clamp protocol was used to simulate an action potential (Fig. 10A). A depolarization to $+30 \mathrm{mV}$ lasting for $2 \mathrm{msec}$ was followed by a shoulder to $0 \mathrm{mV}$ lasting $10 \mathrm{msec}$. Figure $10 B$ shows the current elicited by the action potential simulation, and superimposed on this is the current during a depolarization to $0 \mathrm{mV}$ (shoulder phase). The $2 \mathrm{msec}$ depolarization to $+30 \mathrm{mV}$ did not relieve the inhibition induced by 5-HT (Fig. 10C,D). To determine whether relief from the effects of 5-HT might occur physiologically, trains of depolarizations, mimicking action potentials, were applied. First, a current elic-
A
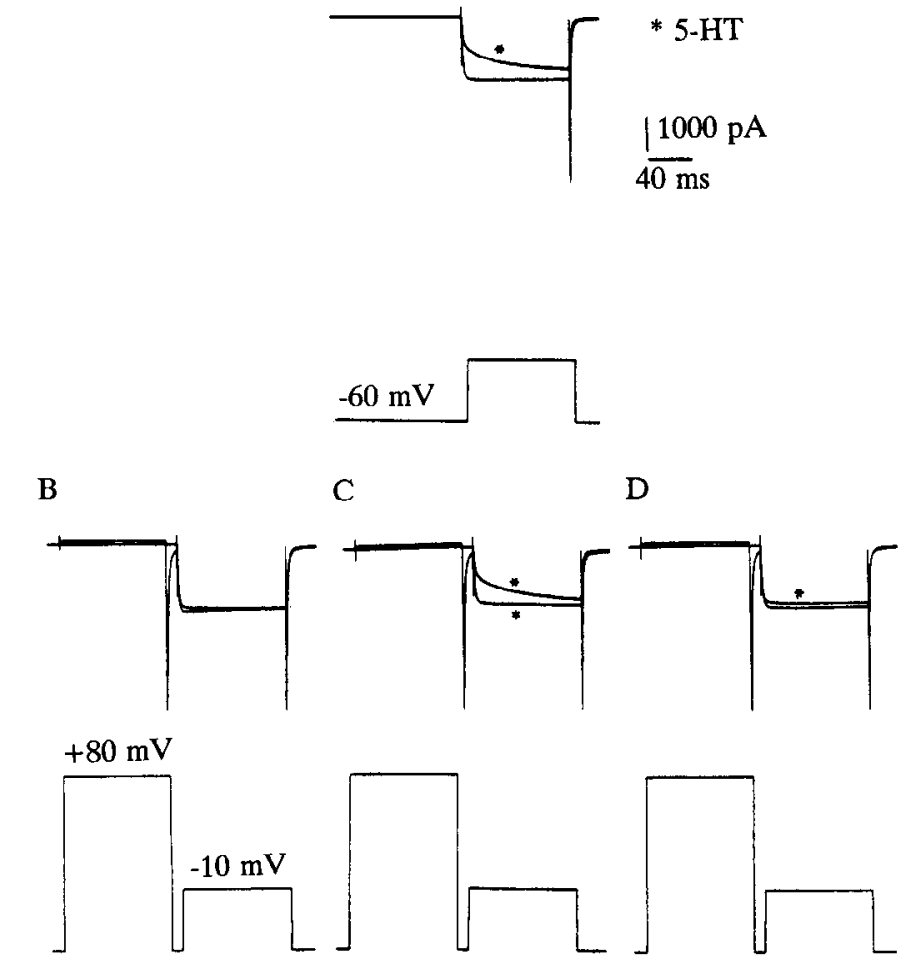

$\mathrm{E}$

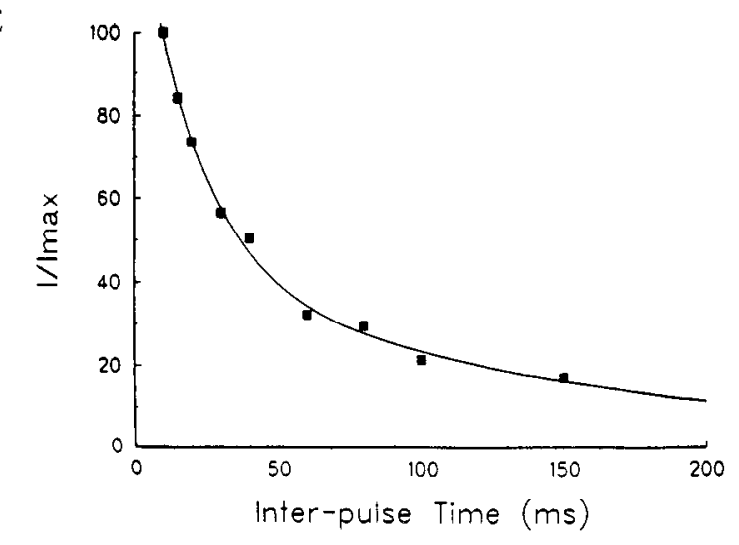

Figure 9. Positive predepolarizations eliminated the inhibitory effects of 5-HT. $A$ shows the inhibition produced by $10 \mu \mathrm{M} 5$-HT in the absence of prepulses. $B$ shows two current traces elicited by test pulses to -10 $\mathrm{mV}$, in the absence of 5-HT. One test pulse was preceded by a prepulsc to $+80 \mathrm{mV}$. $C$ plots Ca current obtained in the presence of $5-\mathrm{HT}(10$ $\mu \mathrm{M}$ ), elicited by a voltage step from $\mathrm{hp}=-60 \mathrm{mV}$ to $-10 \mathrm{mV}$. Superimposed on this is a sweep that included a $100 \mathrm{msec}$ prepulse to +80 $\mathrm{mV}$, followed by a return to the holding potential for $10 \mathrm{msec}$ to allow the $\mathrm{Ca}$ tail current to decay. $D$ plots the $\mathrm{Ca}$ current in 5-HT but after a prepulse to $+80 \mathrm{mV}$, and superimposed on this is the control $\mathrm{Ca}$ current before 5-HT was added. (In some cells, depolarizing prepulses completely abolished the effect of 5-HT.) $E$, Time course of recovery from the effects of a prepulse to $+80 \mathrm{mV}$. The experiment was conducted as shown in $A$, but the time between the prepulse and the test pulse was progressively increased from 10 to $150 \mathrm{msec}$. Recovery from the effects of a prepulse is expressed as a percentage of the current recovered during an interpulse interval of $10 \mathrm{msec}$. The effect of the prepulse decayed with a timc course well fit by the sum of two cxponcntials (onc of 20 $\mathrm{msec}$ and the second of $145.5 \mathrm{msec}$ for this cell). The function used was $Y=A_{1} \times \exp ^{\left(-t / \tau_{1}\right)}+A_{2} \times \exp ^{(-t / 2)}$, where $A_{1}=94.2, \tau_{1}=20 \mathrm{msec}, A_{2}$ $=44.7$, and $\tau_{2}=145.5 \mathrm{msec}$. The data were fit with a simplex algorithm. 


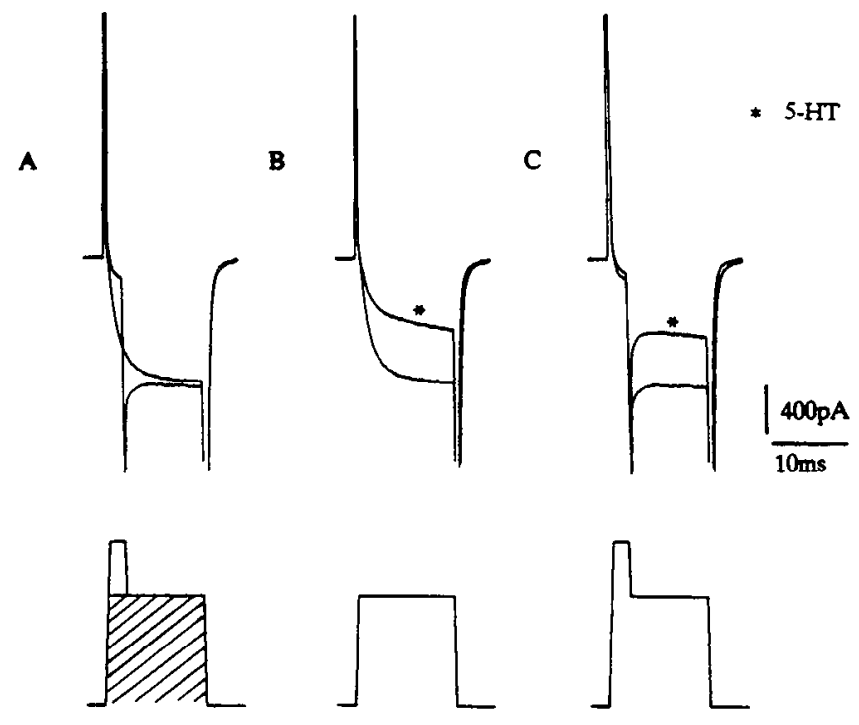

D
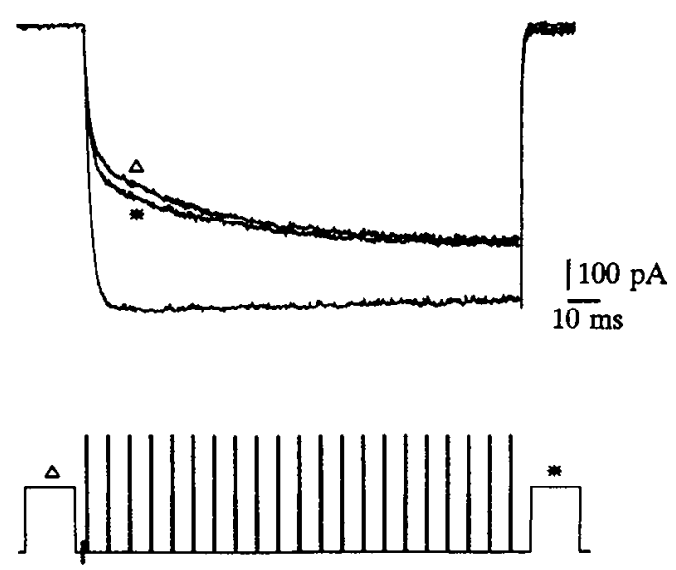

Figure 10. Depolarizations mimicking single action potentials and the effect of 5-HT on calcium current. $A$, Idealized action potentials were constructed as follows: a ramp from -60 to $+30 \mathrm{mV}$ depolarized the cell. The cell was maintained at $+30 \mathrm{mV}$ for $2 \mathrm{msec}$, representing the activation of $\mathrm{Na}$ channels. This was followed by a ramp from +30 to $0 \mathrm{mV}$. The cell was maintained at $0 \mathrm{mV}$ for $10 \mathrm{msec}$, representing $\mathrm{Ca}$ channel activation ( $\mathrm{Ca}$ shoulder). Depolarizations were applied with and without the initial component to $+30 \mathrm{mV}$. More current flows at $0 \mathrm{mV}$ after the full action potential simulation due to the fact that additional channels were activated at $+30 \mathrm{mV}$ that deactivate at $0 \mathrm{mV}$. $B$ shows the effect of $10 \mu \mathrm{M}$ 5-HT (marked with an asterisk) on the Ca current in response to the shoulder phase only of the model action potential. 5-HT caused a slowing of the rate of activation and a large inhibition of the Ca current. $C$ shows that the depolarization to +30 $\mathrm{mV}$ (Na component) did not reduce the inhibitory effect of 5-HT on the Ca currents. $D$, Trains of depolarizations mimicking action potentials failed to overcome the 5-HT-mediated inhibition of DR neuron $\mathrm{Ca}$ currents. The $\mathrm{Ca}$ current was measured at $-10 \mathrm{mV}(\mathrm{hp}=-60 \mathrm{mV})$. A train of 21 depolarizations to $+30 \mathrm{mV}$, each lasting $5 \mathrm{msec}$ and occurring every $60 \mathrm{msec}$, was applied. Sixty milliseconds after the last pulse, the $\mathrm{Ca}$ current was measured again. The protocol had little effect in the presence of $10 \mu \mathrm{M} 5-\mathrm{HT}$ (trace marked with an asterisk). The train increased the Ca current by $5 \%$. When trains vith 60 pulses were used, the Ca current was slightly decreased. In the ausence of 5-HT, the trains had little effect as well. The break in the voltage protocol marked with two parallel bars represents a gap of $20 \mathrm{sec}$. ited by a test pulse from $\mathrm{hp}=-60 \mathrm{mV}$ (close to a physiological resting potential) to $-10 \mathrm{mV}$ was recorded in the presence of $5-\mathrm{HT}$. This was followed by a train of 21 simulated action potentials that were voltage-clamp depolarizations to $+30 \mathrm{mV}$ from $\mathrm{hp}=-60 \mathrm{mV}$ lasting $5 \mathrm{msec}$ (typically the maximum potential reached in a DR neuron action potential was only +15 $\mathrm{mV}$ ), applied 16 times per sec [twice the maximal rate observed in DR neurons in vivo (Hcym ct al., 1982)]. Sixty milliseconds after the train of simulated action potentials, a second test pulse to $-10 \mathrm{mV}$ was administered to determine whether there was any relief of 5-HT-mediated inhibition. Figure $10 D$ illustrates that the train had virtually no effect (in four experiments there was an average increase in Ca current of 5\% after trains). Trains of different durations (of 5, 16, or 60 depolarizations) were also without significant effect. These data suggest that even if raphe neurons are induced to fire at rates somewhat faster than those observed under physiological conditions, reversal of 5-HT-mediated inhibition was not observed.

\section{Mechanism of 5-HT inhibition: possible direct interactions with G-proteins}

Responses to 5-HT were always readily reversible upon washing the 5-HT from the bath (Fig. 6). When $30 \mu \mathrm{M}$ nonhydrolyzable analog GTP- $\gamma$-S (Eckstein, 1985) was added to the pipette to yield a ratio of GTP:GTP- $\gamma$-S of 10:1 (Pfaffinger, 1988), there was no significant effect on the $\mathrm{Ca}$ channel currents for the first 10 min of recording, but the action of 5-HT was no longer reversible $(n=10$; Fig. $11 \mathrm{~A})$. A second application of 5-HT produced only a small additional inhibition of the Ca current (Fig. 11A). Traces before and after the addition of 5-HT are shown in the inset. GTP- $\gamma$-S by itself, in the absence of applied agonist, was able to slowly decrease Ca current amplitude and to slow activation, cellular responses normally elicited by $5-\mathrm{HT}$ (Fig. $11 B$ ). After a long intracellular application of GTP- $\gamma-\mathrm{S}$, 5-HT no longer had a pronounced effect (Fig. 11B).

Figure $11 C$ shows an isochronal $I / V$ relationship obtained after perfusing a DR neuron for an extended period with GTP$\gamma$-S. The current was measured at $8.5 \mathrm{msec}$ after the depolarizing step (the time required for the current to activate fully at +30 $\mathrm{mV}$ ) and plotted as early (isochronal) current. The current was also measured at the end of the $140 \mathrm{msec}$ voltage step (late current). Figure $11 C$ shows that the suppression of DR neuron $\mathrm{Ca}$ current by GTP- $\gamma-\mathrm{S}$ was voltage dependent in a fashion analogous to that of 5-HT (Fig. 8). Large depolarizations were able to reverse the effects of GTP- $\gamma$-S on the early current. As stated above, the inward current activated by $8.5 \mathrm{msec}$ at +30 $\mathrm{mV}$ but the current took $124 \mathrm{msec}$ to reach a steady state at $-10 \mathrm{mV}$. GTP- $\gamma-\mathrm{S}$ slowed Ca current activation from -30 to $+20 \mathrm{mV}$, leading to a differential inhibition of early current relative to late current. When the late and early currents are plotted together (Fig. 11C), it is apparent that the largest inhibition was observed at potentials near $-10 \mathrm{mV}$.

GDP- $\beta$-S (a guanosine nucleotide analog that binds with a slow off-rate but is thought not to activate G-proteins) in the patch pipette at $500 \mu \mathrm{M}$ could alter the action of 5-HT. In all figures showing current/time plots, the response to $5-\mathrm{HT}$ was maximal after about $40 \mathrm{sec}$, mostly due to the dead time of the perfusion system. By contrast, when GDP- $\beta$-S was included in the patch pipette, in the absence of GTP, the response to 5-HT often took over $10 \mathrm{~min}$ to develop $(n=6)$. In the presence of GTP, GDP- $\beta$-S had little effect in two cells and slowed the onset of the response in another. The slowing of the onset of the 
A

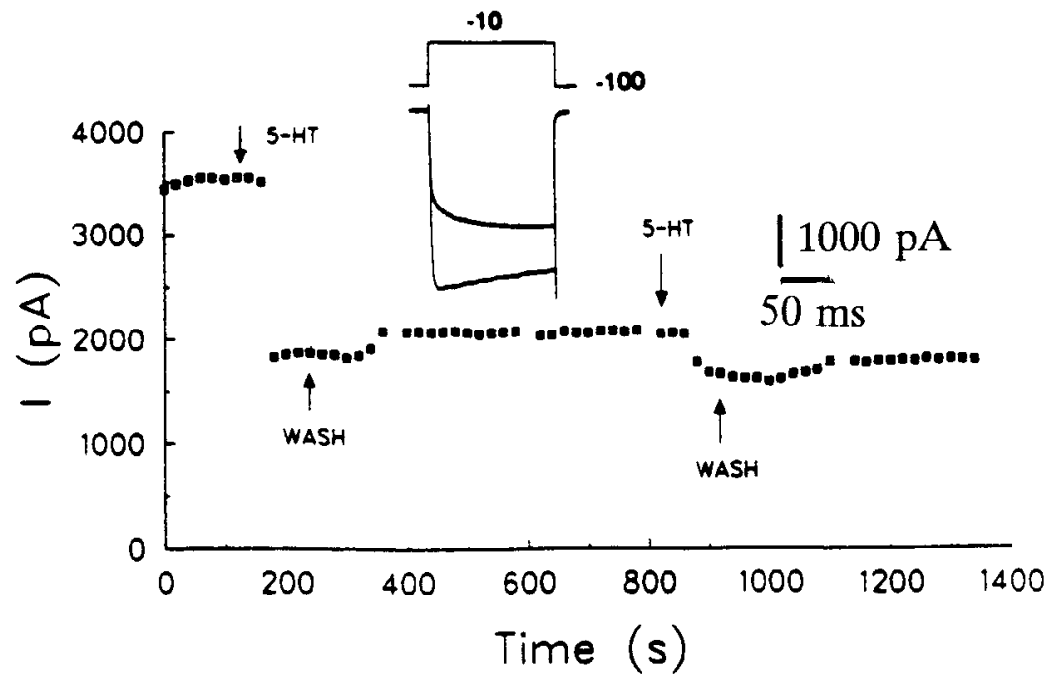

B

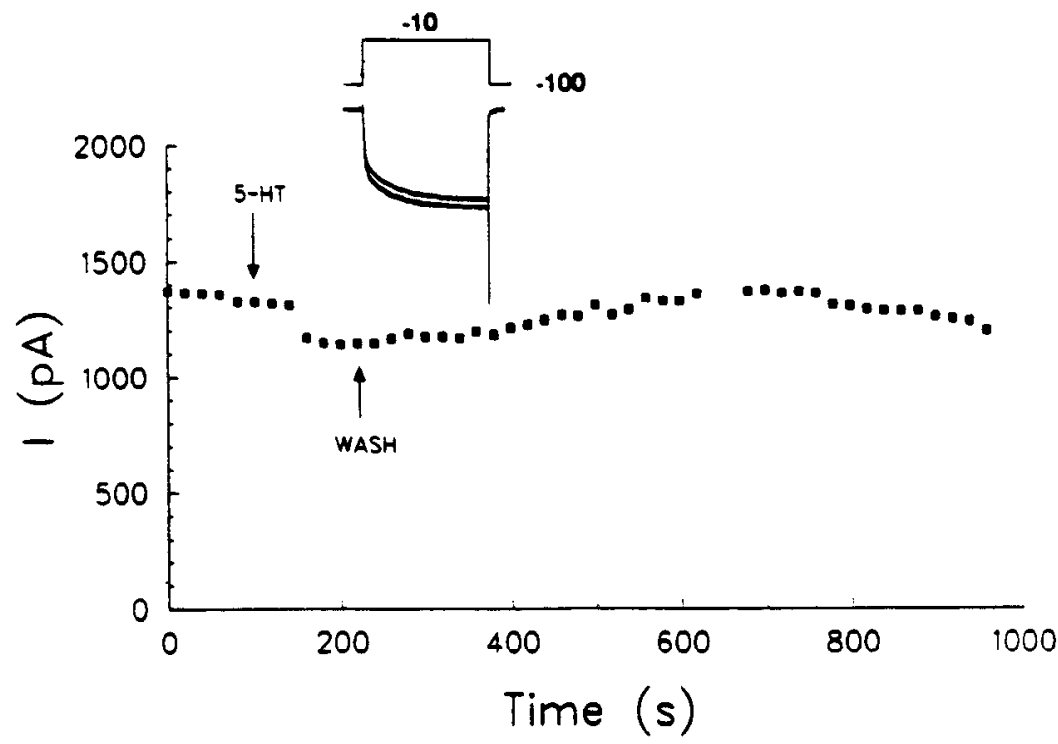

C

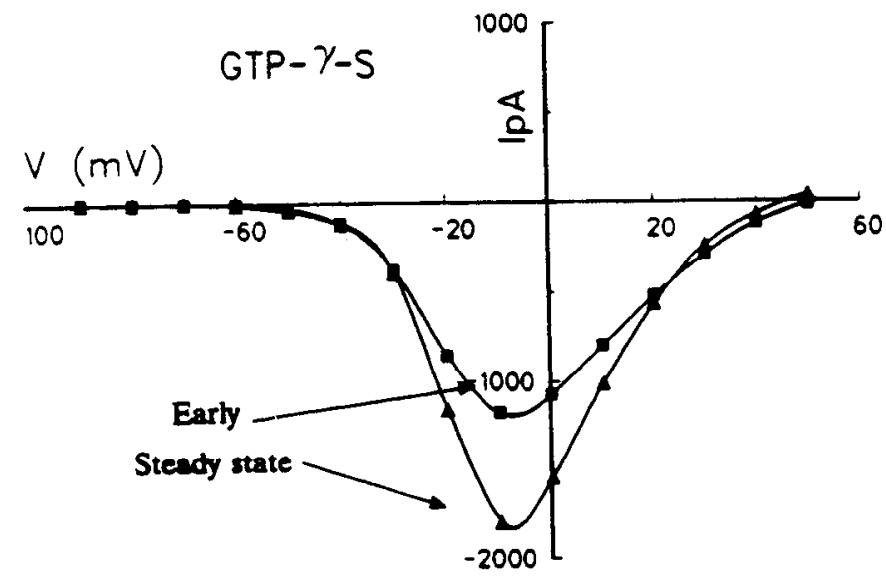

Figure 11. Intracellular GTP- $\gamma-\mathrm{S}$ rendered the response to 5-HT irreversible. $A$, The inclusion of $30 \mu \mathrm{M}$ GTP$\gamma$-S with $300 \mu \mathrm{M}$ GTP in the patch pipette generally had little effect for the first $10 \mathrm{~min}$ of recording. 5-HT $(10 \mu \mathrm{M})$ was added at the first arrow (3.5 min after breaking into the cell), as indicated. Little recovery was observed upon washing the 5-HT out of the bath (second arrow). 5-HT was reapplied at the third arrow and washed out at the fourth arrow. Currents before and after the application of 5-HT are shown in the inset. $B$, After dialyzing DR neurons for longer times with GTP- $\gamma-$ S, Ca currents already showed the characteristic slow activation normally associated with 5-HT (in this cell 5-HT was first added at $6.5 \mathrm{~min}$ after breaking into the cell). Addition of 5-HT produced only a small additional effect. The inset shows the effect of 5-HT. $C$ plots isochronal peak current as a function of voltage. Both carly and late currents were measured and plotted. The suppression of Ca current by GTP- $\gamma-\mathrm{S}$ was both time and voltage dependent. The difference between the two plots indicates the potentials over which 5-HT slows the activation of $\mathrm{Ca}$ current. 
response to 5-HT was probably due to a direct action of GDP$\beta$-S and not the absence of GTP as the response to 5-HT washed out when GTP (and GDP- $\beta-S$ ) was excluded from the pipette $(n=1)$.

In DRG neurons, protein kinase $\mathrm{C}$ (PKC) has been shown to mimic the $\mathrm{Ca}$ current inhibition produced by noradrenaline (Rane et al., 1989; but see Hockberger et al., 1989). In order to test whether PKC mediates the action of 5-HT in DR neurons, the effects of 12,13-phorbol dibutyrate (PDBU), a PKC activator, were examined. With $\left[\mathrm{Ca}^{2+}\right]_{i}$ buffered to $100 \mathrm{nM}$ using $5.6 \mathrm{mM} \mathrm{Ca}^{2+}$ and $11 \mathrm{~mm}$ EGTA in the internal solution, PDBU caused a large but slow-onset inhibition of the Ca current (Fig. $12 A$ ) with no apparent change in activation kinetics. 5-HT still inhibited $\sim 50 \%$ of the Ca current after PDBU treatment and slowed the activation kinetics, indicating that the two effects were probably mediated by different mechanisms. [Superfusion with PDBU $(100 \mathrm{nM})$ in cells when $\left[\mathrm{Ca}^{2+}\right]_{i}$ was buffered below $5 \mathrm{nM}(n=4)$ yielded variable results. In two cells, Ca current was slightly increased, and in the remaining cells PDBU had no effect. In all cases, the response to 5-HT was normal.]

The possibility that 5-HT may inhibit DR neuron Ca current by raising the intracellular levels of cAMP was examined by applying membrane-permeant cAMP analogs to the bath. 8-BrcAMP $(n=2)$ and 8-chlorophenylthio-cAMP (8-CPT-cAMP; $n=2$ ) both had small variable effects. In one cell, 8-Br-cAMP produced a small increase (10.4\%), and in another there was a small decrease (12.9\%) in the Ca current amplitude. 8-CPTcAMP $(100 \mu \mathrm{M})$ had no effect in one cell and caused a transient (20\%) decrease in Ca current in another. These compounds had no effect on Ca current activation. 8-Br-cGMP (1 mM) similarly did not mimic the effect of 5-HT $(n=2)$.

$\mathrm{H}-7$ is a nonspecific protein kinase inhibitor that competes with ATP binding at a conserved catalytic domain in a wide variety of kinases (see review in Nestler and Greengard, 1989). To test whether protein kinases were involved in the response to $5-\mathrm{HT}, \mathrm{H}-7$ was included in both the bathing medium $(50 \mu \mathrm{M}$; $n=5)$ and also in the patch pipette $(200 \mu \mathrm{M} ; n=9)$. Figure $12 B$ illustrates that $\mathrm{H}-7$ was not able to prevent $\mathrm{Ca}$ current inhibition produced by $5-\mathrm{HT}$ in 14 DR neurons.

Arachidonic acid (AA) has been shown to inhibit Ca current in cultured chick sympathetic neurons (Bug et al., 1989). In DR neurons, AA produced essentially identical findings to those obtained with PDBU. AA (50 $\mu \mathrm{M})$ caused a similar large, slowonset inhibition of Ca current but did not change the kinetics of activation of the current (Fig. 12C;n=6). The effect was not reversible (using a lower concentration of $10 \mu \mathrm{M}$, Bug et al. (1989) found that AA inhibition of Ca current was reversible). In one experiment, $10 \mu \mathrm{M}$ AA had no effect on a DR neuron Ca current. 5-HT was still capable of inhibiting $\sim 50 \%$ of the remaining current and slowing the activation rate of the current (Fig. 12C). In these experiments using AA, there was no added $\mathrm{Ca}$ in the pipette solution and the internal $\mathrm{Ca}^{2+}$ was probably buffered below $1 \mathrm{nM}$. As the effect of PDBU seemed to require intracellular $\mathrm{Ca}^{2+}$ levels near those observed under physiological conditions while AA did not, it may be that the two compounds work via different pathways.

\section{The involvement of an easily diffusible second messenger in the response to 5-HT}

Single-channel experiments were carried out to determine whether an easily diffusible second messenger was involved in the response to 5-HT. In the cell-attached patch-clamp configuration, 5-HT, when added to the bath, would be prevented from reaching the $\mathrm{Ca}$ channels by the patch pipette. Any effects observed on channel gating would likely be due to a freely diffusible second messenger. Figure 13 shows a typical experiment where 5-HT was added to the bath outside the patch pipette. Unitary currents without (Fig. 13A) and with 5-HT (200 $\mu$ M; Fig. $13 B$ ) present in the bath are shown from a patch that expressed predominantly $\mathrm{N}$-type activity. Ensemble average currents are plotted below. No effect of 5-HT was apparent. In 11 experiments where 5-HT was added outside the patch pipette, no obvious effect was observed on channel gating. In three cells, there was a slight diminution of channel activity at the beginning of the sweep (in the ensemble), but this effect was small. In six cells there was no decrease in the ensemble $\mathrm{Ca}$ channcl current, and in two of these cells the ensemble current was slightly increased both at the beginning and at the end of the sweep. These results are in agreement with the data in Figure 12, which showed that the coupling between the 5-HT receptor and the Ca channel did not involve an easily diffusible second messenger, or a protein kinase.

\section{Discussion}

DR neurons have Ca channels that are similar to T-, N-, and L-type Ca channels previously described (Tsien et al., 1988). The L-type Ca channel was sensitive to DHP agonists and antagonists, had a $23 \mathrm{pS}$ slope conductance, and was relatively insensitive to changes in holding potential. Using DHP antagonists as a probe for L-type Ca channels, it was found that L-channels contributed only a small amount of the total DR neuron $\mathrm{Ca}$ current $(\approx 4 \%)$. Even so, in single-channel experiments with the DHP agonist BAY K 8644 in the bath, L-type Ca channels were found in almost every patch.

T-type Ca currents were only observed when using negative holding potentials and had a slope conductance of $8 \mathrm{pS}$. At the unitary current level, channel activity clustered at the beginning of the sweep, demonstrating the transient nature of this current component. In the past, low-threshold action potentials as well as repetitive or pacemaker activity have all been attributed to T-type channels (Llinas and Yarom, 1981; Tsien et al., 1988). In DR neurons, $\mathrm{T}$-type $\mathrm{Ca}$ channels probably gave rise to the low-threshold $\mathrm{Ca}$ spikes recorded in current clamp, and they may play a prominent part in the spontaneous activity observed. Interestingly, even though low-threshold action potentials were a common feature of DR neurons, the amplitude of the T-type Ca current, measured in whole-cell voltage clamp, was typically small.

In DR neurons, N-type Ca currents required negative holding potentials to reprime fully. They had a slope conductance of 15 $\mathrm{pS}$ and were insensitive to DHPs but were blocked, at least in part, by $\omega$-CgTx. When $\omega$-CgTx was used to block selectively all N-type Ca channels (Plummer et al., 1989; Sah et al., 1989), about $40 \%$ of the total current elicited from $-100 \mathrm{mV}$ was identified as $\mathrm{N}$-type. The majority of the remaining $\mathrm{Ca}$ current (about 50\%) appeared similar to N-type current in that it was high threshold, was somewhat transient, was insensitive to DHPs, and required negative holding potentials to reprime completely. Nonetheless, it was unaffected by $\omega-\mathrm{CgTx}$. Whether these data suggest two components of $\mathrm{N}$-channel current, one sensitive to $\omega-\mathrm{CgTx}$ and the other not, or the existence of a completely new kind of Ca channel, is unclear. DHP- and $\omega$-CgTx-insensitive $\mathrm{Ca}$ currents have been found in other types of neurons (Sah et 
A

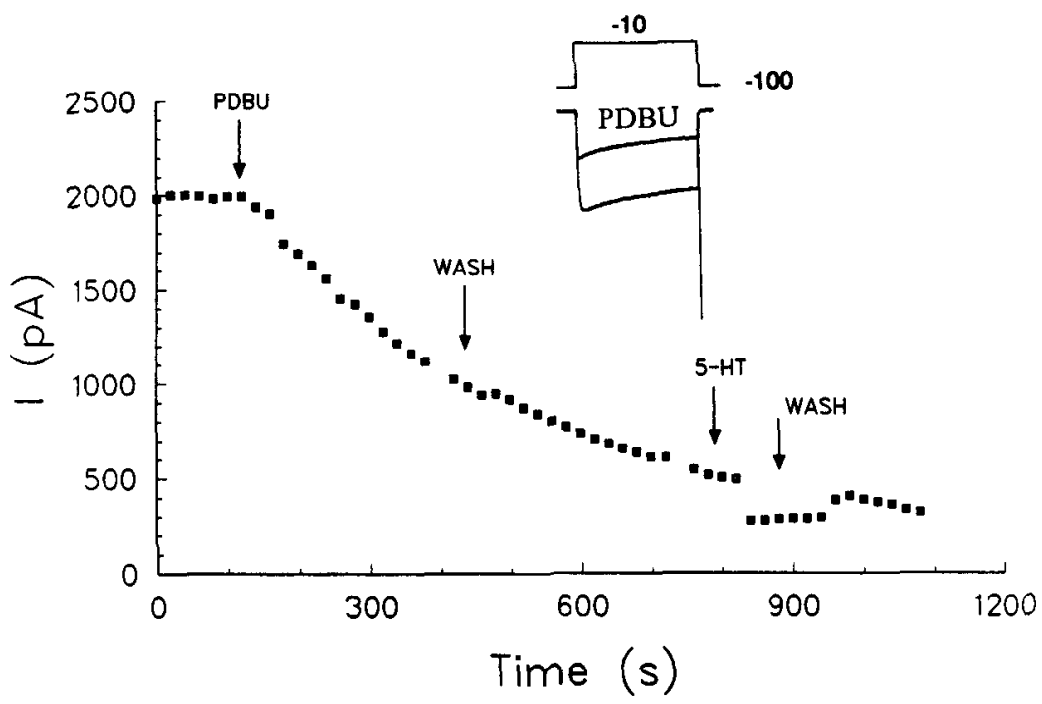

B

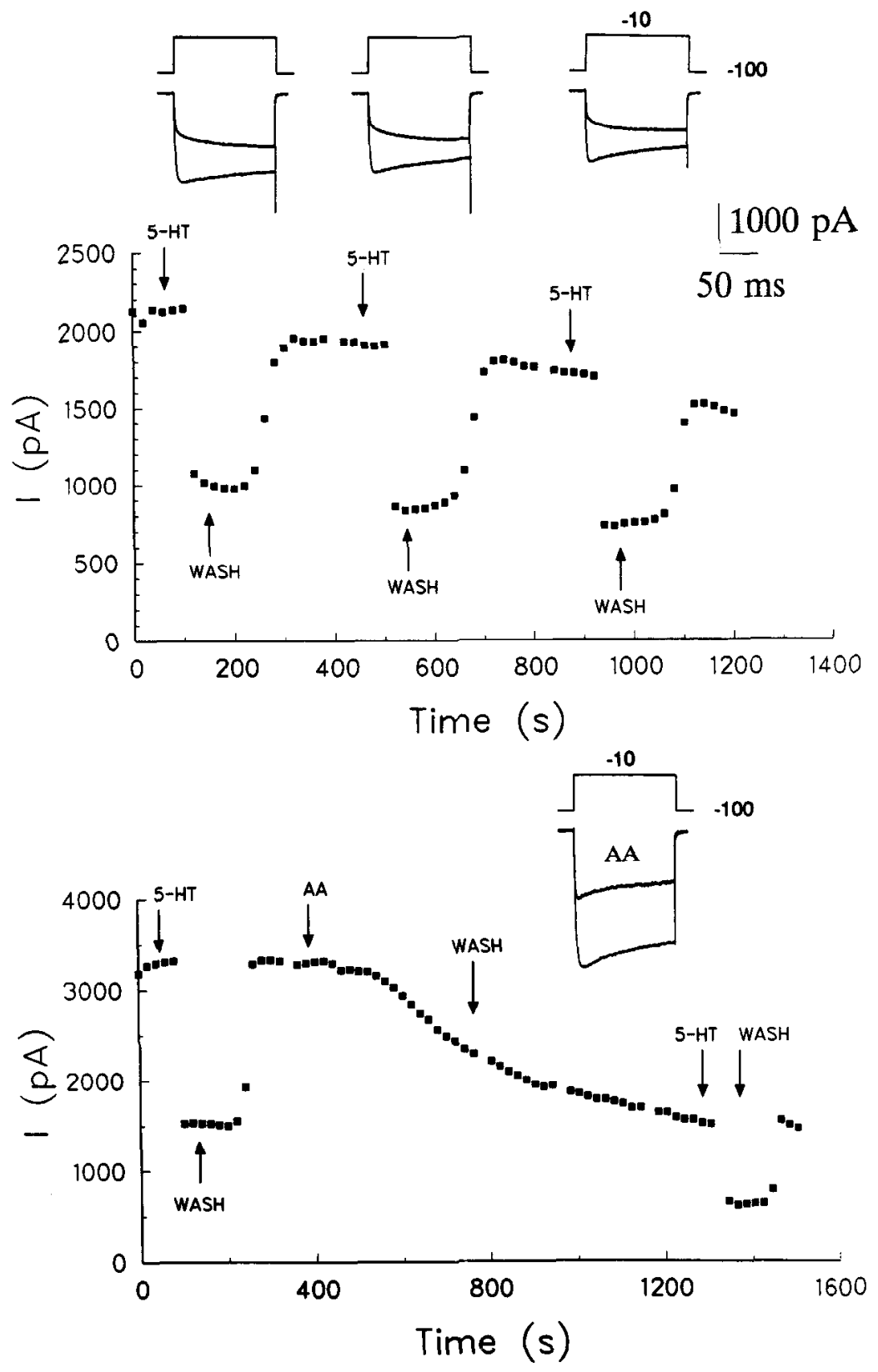

Figure 12. No protein kinases appeared to be involved in the response to $5-H T$. A, Plots of peak current versus time. At the first arrow, $P D B U(100 \mathrm{~nm})$, a PKC activator, was applied, resulting in a slow inhibition of Ca current without any change in activation kinetics (see inset). No recovery was observed upon washing the PDBU from the bath (second arrow). Application of 5-HT(10 $\mu \mathrm{M})$ at the third arrow caused a typical inhibition of the $\mathrm{Ca}$ current along with a slowing of activation. $B, 5-H T$ was still able to inhibit DR neuron Ca currents even after incubation with the nonspecific kinase inhibitor $\mathrm{H}-7$ (50 $\mu \mathrm{M})$. H-7 (200 $\mu \mathrm{M})$ was also included in the patch pipette. The inset shows currents before and after $5-H T$, but in presence of $\mathrm{H}-7 . C, A A$ (free acid or $\mathrm{Na}^{+}$ salt at $50 \mu \mathrm{M}$ ) produced effects indistinguishable from those of $P D B U$. $A A$ added at the arrow reduced the Ca current without changing activation kinetics (see inset). $5-H T$ was able to reduce $\mathrm{Ca}$ current further and slow the rate of the activation of $I_{\mathrm{Ca}}$ in the presence of $A A$. 
A
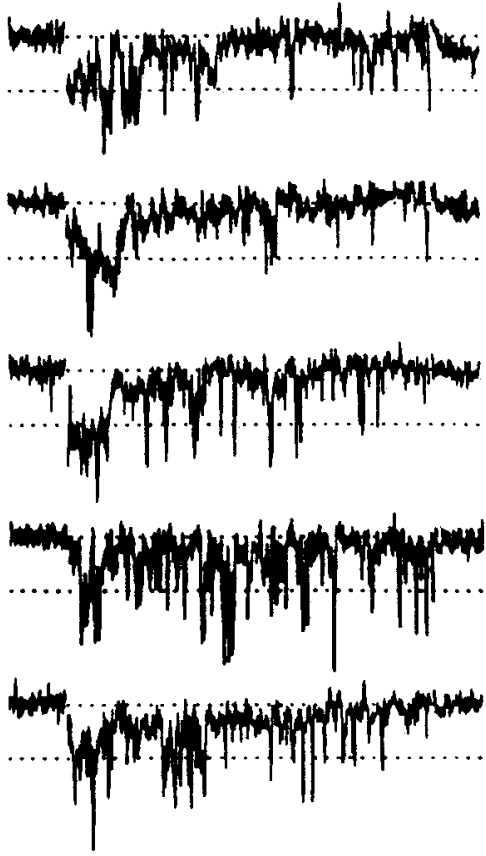

Figure 13. Addition of 5-HT outside a cell-attached patch pipette did not alter single calcium channel gating in DR neurons, indicating that an easily diffusible second messenger was not involved in the response to 5-HT. The cell was bathed in $140 \mathrm{~mm} \mathrm{~K} \mathrm{~K}^{+}$-aspartate to zero the membrane potential (see Materials and Methods), and the patch potential was stepped to $0 \mathrm{mV}$ every 4 sec. $A$ and $B$ show unitary activity recorded in the absence and presence of 5 -HT $(200 \mu \mathrm{M})$. Ensemble averages were made by averaging 62 sweeps of channel activity (and 74 in the presence of 5-HT) and are plotted below. The patch illustrated contained T-type and N-type channels and an L-type channel that opened briefly (to about twice the unitary current level of the N-type channel).

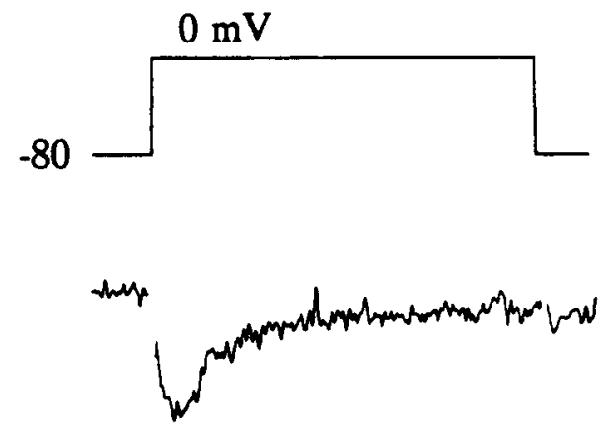

B
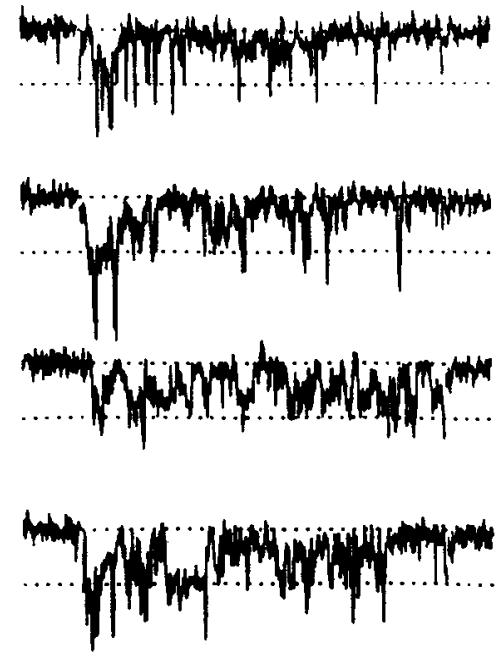

$1 \mathrm{pA}$

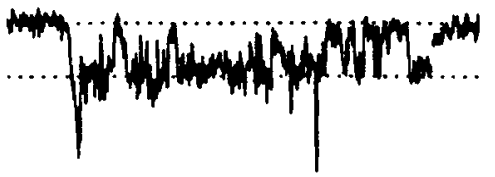

$20 \mathrm{~ms}$

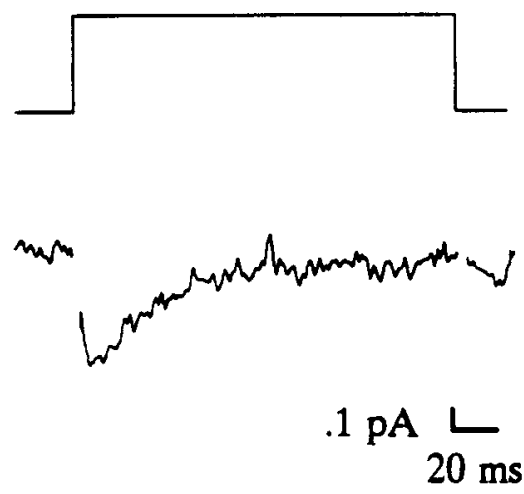

al., 1989; Mogul and Fox, 1991). The DHP- and $\omega$-CgTx-insensitive component of Ca current may be carried by P-type or NEN-type Ca channels (Lester et al., 1989; Llinas et al., 1989). Currently, there is no good single-channel characterization of Ca channels that do not fit into the $\mathrm{T}-\mathrm{N}, \mathrm{N}$-, or L-type categorization. An experiment that may help resolve the discrepancy between the three classes of single channels detected and the four components of whole-cell current observed would be the application of $\omega-\mathrm{CgTx}$ to outside-out nystatin-perforated vesicles. Our results suggest that while the T, N, and L Ca channel classification originally developed for peripheral neurons is still applicable, it is not sufficient for a complete description of adult raphe neuron $\mathrm{Ca}$ channels.

5-HT inhibited about $50 \%$ of the peak DR neuron Ca current (Penington and Kelly, 1990). 5-HT also dramatically slowed the rate of Ca current activation. As T-type Ca current was unaffected by 5-HT (Penington and Kelly, 1990) and the whole-cell
DR neuron current was composed of only about 4\% L-type current, it was unlikely that either channel type was the primary target for 5-HT-mediated inhibition. N-type Ca channels were inhibited by 5-HT. The total current suppressed by 5-HT was smaller after treatment with $\omega-\mathrm{CgTx}$ than it was before treatment. Nonetheless, a robust response to 5-HT remained even after $\omega-\mathrm{CgTx}$ was applied. These results suggest either that the DHP- and $\omega$-CgTx-insensitive current was $\mathrm{N}$-type current that was insensitive to $\omega-\mathrm{CgTx}$ but that was sensitive to $5-\mathrm{HT}$, or that it was a $\mathrm{Ca}$ channel different from N-type but that was sensitive to 5-HT. The second hypothesis proposes that inhibition by 5 -HT may span classes of channels. Either way, these results imply that the pharmacological properties of DR neurons are quite complex.

Two early reports suggested that the effect of neurotransmitters on neuronal calcium current was time and voltage dependent (Marchetti et al., 1986; Tsunoo et al., 1986), but at the 
time it was suggested that the positive voltages might displace transmitter binding. Later, it was appreciated that positive voltages also reversed the effects of GTP- $\gamma-S$ and thus were clearly working inside the cell (Kasai and Aosaki, 1989; Elmslie et al., 1990). Large depolarizations could also overcome the inhibition produced by noradrenaline and LHRH in peripheral neurons (Bean, 1989; Elmslie et al., 1990). Bean (1989) proposed a model to account for these observations; the majority of $\mathrm{Ca}$ channels dwell in a closed state from which they are "willing" to leave (to open) upon depolarization. Noradrenaline promoted a second state from which the channels were "reluctant" to leave after depolarization. Depolarizations to near $0 \mathrm{mV}$ converted "reluctant" to "willing" channels slowly, accounting for the greatly slowed activation kinetics. Large depolarizations rapidly converted all channcls to a "willing" statc, explaining why the noradrenaline had small effects at positive potentials. At the single-channel level, these changes may be reflected in different types of gating behaviors (Lipscombe et al., 1989).

Large depolarizations could overcome the inhibitory effects of 5-HT on DR neuron Ca currents, in a fashion analogous to that observed in peripheral neurons. It might be argued that a depolarizing pulse may cause an apparent reversal of the action of 5-HT due to the recruitment of calcium channels unrelated to the ones inhibited by $5-\mathrm{HT}$. This, however, is unlikely because prepulses were shown to increase the control calcium channel current by only $5 \%$. Prepulses to $+80 \mathrm{mV}$ could reverse the 5-HT-mediated inhibition observed during subsequent test pulses. This means that once the prepulse to $+80 \mathrm{mV}$ made the Ca channels "willing" they remain in that state for at least a short period of time. To determine how long channels could remain "willing" in the presence of 5-HT, a two-pulse voltage protocol was employed where the interval between the prepulse (to $+80 \mathrm{mV}$ ) and the test pulse was lengthened. In the presence of 5-HT (at hp $=-60 \mathrm{mV}$ ), leaving the "willing" state to return to the "reluctant" state was a biexponential process with time constants in the 14 and $120 \mathrm{msec}$ range. These results suggested that if "physiological" stimuli like action potentials depolarized DR neurons to positive enough potentials for sufficient periods of time to convert $\mathrm{Ca}$ channels from "reluctant" to "willing" states, then trains of action potentials might be able to overcome the 5-HT-mediated inhibition of the Ca current. Although an individual action potential might only convert a few $\mathrm{Ca}$ channels from "reluctant" to "willing," the effect of many action potentials might summate. This hypothesis was tested using criteria specific to DR neurons. DR neurons in vivo normally fire at a very regular rate between 1 and $3 \mathrm{~Hz}$ for most of the sleep/wake cycle, with a notable exception of rapid eye movement (REM) sleep, when they are almost silent (Trulson and Jacobs, 1979). This is probably due to strongly rectifying outward $\mathrm{K}^{+}$conductances $I_{K}, I_{A}$, and $I_{\text {Cag } K}$ (Aghajanian, 1985) as well as extensive GABAergic and serotonergic recurrent inhibition (Pan and Williams, 1989). A sudden sensory input like a flash of light or a sound will cause the cells to fire for about a second at a maximum rate of about $7 \mathrm{~Hz}$ (Heym et al., 1982). DR neurons can be excited for several seconds by sensory input (Heym et al., 1982). With this information, we chose to use trains of 5 to 60 depolarizations to represent the range of DR neuron behavior. Trains of action potentials were applied at 16 action potentials/sec, more than twice the physiologial maximum rate. To simulate individual action potentials, DR neurons were depolarized to $+30 \mathrm{mV}$ for $5 \mathrm{msec}$ (action potentials, recorded either from slices or acutely isolated neurons, typically were to approxi- mately $+15 \mathrm{mV}$ and lasted for $5 \mathrm{msec}$ at $22^{\circ} \mathrm{C}$ ). Trains of simulated action potentials were not able to overcome the 5-HTmediated inhibition of DR Ca currents. While large depolarizations could reverse the effect of 5-HT, physiological stimuli, such as action potentials, could not. Do these results reflect the relatively slow firing rates of raphe neurons, or will the inability of action potentials to reverse the inhibition of $\mathrm{Ca}$ channels by neurotransmitters be a general property found in all neurons? These questions will only be answered by studying Ca channel inhibition in rapidly firing neurons such as thalamic or hippocampal neurons. Nonetheless, it seems unlikely that inhibition of Ca currents by neurotransmitters in slowly firing neurons will be prevented by changes in endogenous action potential firing rates. In view of the similarity of the Ca current suppression mcdiated by inhibitory neurotransmitters in a variety of central and peripheral neurons, it is possible that the results of this study will be applicable to other nerve cells (it should be noted that the studies of action potential firing were done in vivo at $37^{\circ} \mathrm{C}$ while our study was done at $22^{\circ} \mathrm{C}$ ).

Including GTP- $\gamma-\mathrm{S}$ in the patch pipette rendered irreversible the normally reversible 5-HT suppression of DR neuron $\mathrm{Ca}$ current (Holz et al., 1986; Dolphin and Scott, 1987; Hescheler et al., 1987; Ewald et al., 1988), implying that G-proteins were probably involved in mediating the response to 5 -HT. Perfusing GTP $-\gamma-S$ into raphe neurons for a long duration mimicked the actions of 5-HT, including the voltage-dependent effects. These findings suggest that the voltage dependency of the 5-HT response is probably not due to voltage-dependent unbinding of 5-HT from the receptor at positive potentials but rather is due to the voltage dependence of a step occurring after the receptorligand interaction.

The role of second and third messenger systems in mediating the response to 5-HT was also addressed in this study. Response cascades were tested that have been shown to be effective in other neuronal preparations. For instance, activators of PKC inhibited hippocampal Ca currents (Doerner et al., 1988) and mimicked the action of noradrenaline on cultured chick DRG neurons (Rane and Dunlap, 1986). Inhibitors of PKC prevented noradrenaline from suppressing DRG Ca currents (Rane et al., 1989). In contrast, Hockberger et al. (1989) found that the inclusion of PKC activators and inhibitors in the patch pipette did not affect the inhibition of $\mathrm{Ca}$ currents produced by extracellularly applied phorbol esters in DRG neurons, implying that the phorbol esters suppressed the Ca current directly and did not act via a second messenger. Others have reported increases in single-channel activity after the application of phorbol esters to hippocampal neurons (Doerner and Alger, 1989; Madison, 1989). In DR neurons, we found that the whole-cell Ca current was inhibited by phorbol esters but that this effect did not resemble that of 5-HT, as the inhibition developed slowly over minutes and after the effect was maximal the kinetics of the $\mathrm{Ca}$ current activation was apparently unchanged. Furthermore, the effects of phorbol esters and 5-HT were additive, suggesting that the 5-HT response was not mediated by PKC. AA, which has been reported to activate $\mathrm{PKC}$ in cell-free preparations $(\mathrm{Mu}-$ rakami et al., 1986; Dell and Severson, 1989), produced an inhibition of Ca current similar to that produced by phorbol esters. Neither the activation of protein kinase $A$ nor the activation of cGMP-dependent kinase mimicked the 5-HT-mediated inhibition of DR neuron Ca currents.

$\mathrm{H}-7$ is a nonspecific protein kinase inhibitor that competes with ATP binding at a catalytic domain in a wide variety of 
kinases (see review in Nestler and Greengard, 1989). Supramaximal doses of $\mathrm{H}-7$ were applied both extracellularly and intracellularly. $\mathrm{H}-7$ was not able to block the Ca current inhibition produced by 5-HT in LR neurons, suggesting that phosphorylation by an $\mathrm{H}-7$-sensitive protein kinase was not involved in the response. As protein kinasc $\mathrm{A}$ and $\mathrm{C}$ activators were not capable of mimicking the 5-HT response (under experimental conditions identical to those where 5-HT was shown to inhibit $\mathrm{Ca}$ currents effectively), and because kinase inhibitors did not block the response to 5-HT, a reasonable interpretation of the data would indicate that the activation of either protein kinase A or $\mathrm{C}$ did not mediate the response to $5-\mathrm{HT}$. Finally, when 5-HT was added outside the pipette in single-channel cell-attached recordings, no changes in channel gating were observed. Response cascades involving freely diffusible second or third messengers will usually affect channel gating even when agonists are added outside the patch pipette (see Siegelbaum et al., 1982; Tsien, 1986; Gray and Johnson, 1987; Artalejo et al., 1990). Thus, while various second messengers may modulate $\mathrm{Ca}$ channel gating, they do not appear to mediate the response to 5-HT.

Taken together, these data are most consistent with the idea that the response to $5-\mathrm{HT}$ is mediated by a $\mathrm{G}$-protein that is tightly coupled to DR neuron $\mathrm{Ca}$ channels and that an easily diffusible second messenger need not be involved. Similar conclusions have been reached in other systems based on work with $\mathrm{G}$-protein-linked neurotransmitters acting on calcium and potassium channels on peripheral neurons (VanDongen et al., 1988; Lipscombe et al., 1989; Hirning et al., 1990). As these results have now been reproduced in central neurons that have not been subjected to tissue culture conditions and with several different neurotransmitters in other systems (including LHRH, noradrenaline, and neuropeptide $Y$ ), it may be that a direct $\mathrm{G}$-protein/Ca channel interaction is a general feature of neurotransmitter-mediated inhibition of neuronal $\mathrm{Ca}$ currents and that this interaction gives rise to the voltage-dependent effects observed.

\section{References}

Aghajanian GK (1985) Modulation of a transient outward current in serotonergic neurones by $\alpha_{1}$ receptors. Nature 315:501-503.

Andrade R, Nicoll RA (1987) Pharmacologically distinct actions of serotonin on single pyramidal neurones of the rat hippocampus recorded in vitro. J Physiol (Lond) 394:99-124.

Artalejo CR, Ariano MA, Perlman RL, Fox AP (1990) $D_{1}$ dopamine receptors activate facilitation $\mathrm{Ca}$ channels in chromaffin cells via a cAMP/protein kinase A mechanism. Nature 348:239-242.

Bean BP (1984) Nitrendipine block of cardiac calcium channels: highaffinity binding to the inactivated state. Proc Natl Acad Sci USA 81: 6388-6392.

Bean BP (1989) Neurotransmitter inhibition of neuronal calcium currents by changes in channel voltage dependance. Nature 340:153156.

Bug W, Role L, Siegelbaum SA, Simmons L (1989) Arachidonic acid inhibits calcium current in chick sympathetic neurons. Soc Neurosci Abstr 15:76.8.

Carbone E, Lux HD (1984) A low voltage-activated, fully inactivating $\mathrm{Ca}$ channel in vertebrate sensory neurons. Nature 310:501-502.

Crunelli V, Forda S, Brooks PA, Wilson KCP, Wise JCM, Kelly JS (1983) Passive membrane properties of neurones in the dorsal raphe and periaqueductal grey recorded in vitro. Neurosci Lett 40:263-268.

Dell KR, Severson DL (1989) Effect of cis-unsaturated fatty acids on aortic protein kinase C activity. Biochem J 258:171-175.

Doerner D, Alger BE (1989) Active vs. inactive phorbol ester effects on whole cell calcium current in hippocampal neurons. Soc Neurosci Abstr 15:178.

Doerner D, Pitler TA, Alger BE (1988) Protein kinase C activators block specific calcium and potassium current components in isolated hippocampal neurons. J Neurosci 8:4069-4078.

Dolphin AC, Scott RH (1987) Calcium channel currents and their inhibition by $(-)$-baclofen in rat sensory neurones: modulation by guanine nucleotides. J Physiol (Lond) 386:1-17.

Dunlap K, Fischbach GD (1981) Neurotransmitters decrease the calcium conductance activated hy depolarization of embryonic chick sensory neurones. J Physiol (Lond) 317:519-535.

Eckstein F (1985) Nucleoside phosphothioates. Annu Rev Biochem $54: 367-402$.

Elmslie KS, Zhou W, Jones SW (1990) LHRH and GTP- $\gamma$-S modify calcium current activation in bullfrog sympathetic neurons. Neuron 5:75-80.

Ewald DA, Sternweis PC, Miller RJ (1988) Guanine nucleotide-binding protein $\mathrm{G}_{\mathrm{o}}$-induced coupling of neuropeptide $Y$ receptors to $\mathrm{Ca}^{2+}$ channels in sensory neurons. Proc Natl Acad Sci USA 85:3633-3637.

Fox AP, Nowycky MC, Tsien RW (1987a) Kinetic and pharmacological properties distinguish three types of calcium currents in chick sensory neurons. J Physiol (Lond) 394:149-172.

Fox AP, Nowycky MC, Tsien RW (1987b) Single-channel recordings of three types of calcium channels in chick sensory neurones. J Physiol (Lond) 394:173-200.

Gray R, Johnson D (1987) Noradrenaline and $\beta$-adrenoreceptor agonists increase activity of voltage dependent calcium channels in hippocampal neurons. Nature 327:620-622.

Hamill O, Marty A, Neher E, Sakmann B, Sigworth FJ (1981) Improved patch-clamp techniques for high-resolution current recording from cells and cell-free membrane patches. Pfluegers Arch 391:85100.

Hescheler J, Rosenthal W, Trautwein W, Schultz G (1987) The GTPbinding protein, $G_{0}$, regulates neuronal calcium channels. Nature 325: 445-447.

Hess P, Lansman JB, Tsien RW (1984) Different modes of calcium channel gating behavior favored by dihydropyridine $\mathrm{Ca}$ agonists and antagonists. Nature 311:538-544.

Heym J, Trulson ME, Jacobs BL (1982) Raphe unit activity in freely moving cats: effects of phasic auditory and visual stimuli. Brain Res 232:29-39.

Hirning LD, Fox AP, Mccleskey EW, Olivera BM, Thayer SA, Miller RJ, Tsien RW (1988) Dominant role of N-type Ca channels in evoked release of norepinephrine from sympathetic neurons. Science 239:57-61.

Hirning LD, Miller RJ, Fox AP (1990) Inhibition of calcium currents in cultured myenteric neurons by neuropeptide $\mathrm{Y}$ : evidence for direct receptor/channel coupling. Brain Res 532:120-130.

Hockberger P, Toselli M, Swandulla D, Lux HD (1989) A diacylglycerol analogue reduces neuronal calcium currents independently of protein kinase $C$ activation. Nature 338:340-342.

Holz GG, Rane SG, Dunlap K (1986) GTP-binding proteins mediate transmitter inhibition of voltage-dependent calcium channels. Nature 319:670-672.

IIuguenard JR, Alger BE (1986) Wholc-cell voltage-clamp study of the fading of GABA-activated currents in acutely dissociated hippocampal neurons. J Neurophysiol 56:1-18.

Innis RB, Nestler EJ, Aghajanian GK (1988) Evidence for G-protein mediation of serotonin and $\mathrm{GABA}_{\mathrm{B}}$-induced hyperpolarization of rat dorsal raphe neurons. Brain Res 459:27-36.

Kasai H, Aosaki T (1989) Modulation of Ca-channel current by an adenosine analog mediated by a GTP-binding protein in chick sensory neurons. Pfiuegers Arch 414:145-149.

Kay AR, Wong RKS (1987) Calcium current activation kinetics in isolated pyramidal neurones of the CA1 region of the mature guineapig hippocampus. J Physiol (Lond) 392:602-616.

Kokubun S, Reuter H (1984) Dihydropyridine derivatives prolong the open state of $\mathrm{Ca}$ channels in cultured cardiac cells. Proc Natl Acad Sci USA 81:4824-4827.

Lakoski JM, Aghajanian GK (1984) Hyperpolarization of serotonergic neurons by serotonin and LSD: studies in brain slices showing increased $\mathrm{K}^{+}$conductance. Brain Res 305:181-185.

Lester HA, Snutch TP, Leonard JP, Nargeot J, Curtis BM, Davidson $N$ (1989) Expression of mRNA encoding voltage-dependent $\mathrm{Ca}$ channels in Xenopus oocytes: review and progress report. Ann NY Acad Sci 560:174-182.

Lipscombe D, Kongsamut S, Tsien RW (1989) $\alpha$-Adrenergic inhibition of sympathetic neurotransmitter release mediated by modulation of N-type calcium-channel gating. Nature 340:639-642. 
Llinas R, Yarom Y (1981) Properties and distribution of ionic conductances generating electroresponsiveness of mammalian inferior olivary neurones in vitro. J Physiol (Lond) 315:569-584.

Llinas R, Sugimori M, Cherksey B (1989) Voltage dependent calcium conductances in mammalian neurons: the P channel. Ann NY Acad Sci 560:103-111.

Madison DV (1989) Phorbol esters increase unitary calcium channel activity in cultured hippocampal neurons. Soc Neurosci Abstr 15:16.

Marchetti C, Carbone E, Lux HD (1986) Effects of dopamine and noradrenaline on $\mathrm{Ca}$ channels of cultured sensory and sympathetic neurones of chick. Pfluegers Arch 406:104-111.

Mogul DJ, Fox AP (1991) Evidence for multiple types of Ca channels in acutely isolated hippocampal $\mathrm{Ca}_{3}$ neurones of the guinea-pig. $\mathrm{J}$ Physiol (Lond) 433:259-281.

Murakami K, Chan SY, Routtenberg A (1986) Protein kinase C activation by cis-fatty acids in the absence of $\mathrm{Ca}^{2+}$ and phospholipids. J Biol Chem 261:15424-15429.

Nestler EJ, Greengard P (1989) Protein phosphorylation and the regulation of protein function. In: Basic neurochemistry: molecular, cellular, and medical aspects, 4th ed. New York: Raven.

Nilius B, Hess P, Lansman JB, Tsien RW (1985) A novel type of cardiac calcium channel in ventricular cells. Nature 316:443-446.

North RA, Williams JT, Surprenant A, Christie MJ (1987) $\mu$ and $\delta$ receptors belong to a family of receptors that are coupled to potassium channels. Proc Natl Acad Sci USA 84:5487-5491.

Nowycky MC, Fox AP, Tsien RW (1985a) Three types of neuronal calcium channels with different calcium agonist sensitivity. Nature 316:440-443.

Nowycky MC, Fox AP, Tsien RW (1985b) Long-opening mode of neuronal calcium channels and its promotion by the dihydropyridine calcium agonist Bay K 8644. Proc Natl Acad Sci USA 82:2178-2182.

Pan ZZ, Williams JT (1989) GABA-and glutamate-mediated synaptic potentials in rat dorsal raphe neurons. J Neurophysiol 61:719-726.

Penington NJ, Kelly JS (1990) Serotonin receptor activation reduces calcium current in an acutely dissociated adult central neuron. Neuron 4:751-758

Pfaffinger $P$ (1988) Muscarine and t-LHRH suppress M-current by activating an IAP-insensitive G-protein. J Neurosci 8:3343-3353.

Plummer MR, Logothetis DE, Hess P (1989) Elementary properties and pharmacological sensitivities of calcium channels in mammalian peripheral neurons. Neuron 2:1453-1463.

Rainnie DG, Penington NJ, Kelly JS (1987) On the hyperpolarizing action of 5-HT on dorsal raphe neurones in vitro. Neurosci Lett [Suppl]29:S72.
Rane SG, Dunlap K (1986) Kinase C activator 1,2-oleoylacetylglycerol attenuates voltage-dependent calcium current in sensory neurons. Proc Natl Acad Sci USA 83:184-188.

Rane SG, Walsh MP, Mcdonald JR, Dunlap K (1989) Specific inhibitors of protein kinase $\mathrm{C}$ block transmitter-induced modulation of sensory neuron calcium current. Neuron 3:239-245.

Sah DWY, Regan LJ, Bean BP (1989) Calcium channels in rat neurones: high-threshold channels that are resistant to both $\omega$-conotoxin and dihydropyridine blockers. Soc Neurosci Abstr 15:823.

Sanguinetti MC, Kass RS (1984) Voltage-dependent block of calcium channel current in the calf cardiac Purkinje fibre by dihydropyridine calcium channel antagonists. Circ Res 55:336-348.

Siegelbaum SA, Camardo JS, Kandel ER (1982) Serotonin and cyclic AMP close single $\mathrm{K}^{+}$channels in Aplysia sensory neurones. Nature 299:413-417.

Trulson ME, Jacobs BL (1979) Raphe unit activity in freely moving cats: correlation with level of behavioral arousal. Brain Res 163:135150.

Tsien RW (1986) Calcium channels in heart cells and neurons. In: Neuromodulation (Kaczmarek LK, Levitan IB, eds), pp 206-242. New York: Oxford UP.

Tsien RW, Lipscombe D, Madison DV, Bley KR, Fox AP (1989) Multiple types of neuronal calcium channels and their selective modulation. Trends Neurosci 11:431-437.

Tsunoo A, Yoshii M, Narahashi T (1986) Block of calcium channels by enkephalin and somatostatin in neuroblastoma-glioma hybrid NG108-15 cells. Proc Natl Acad Sci USA 83:9832-9836.

Vandermaelen CP, Aghajanian GK (1983) Electrophysiological and pharmacological characterization of serotonergic dorsal raphe neurones recorded extracellulary and intracellularly in rat brain slices. Brain Res 289:109-119.

VanDongen AM, Codina J, Olate J, Mattera R, Joho R, Birnbaumer L, Brown AM (1988) Newly identified brain potassium channels gated by the guanine nucleotide binding protein $G_{0}$. Science 242 : $1433-1437$.

Wang RY, Aghajanian GK (1977) Antidromically identified serotonergic neurones in the rat midbrain raphe: evidence for collateral inhibition. Brain Res 132:186-193.

Williams JT, Colmers WF, Pan ZZ (1988) Ligand and voltage activated inwardly rectifying currents in dorsal raphe neurons in vitro. J Neurosci 8:3499-3506. 